University of Montana

ScholarWorks at University of Montana

Graduate Student Theses, Dissertations, \&

Professional Papers

1989

\title{
Maxillary canine/third premolar transposition in a prehistoric population from Santa Cruz Island California
}

Greg C. Nelson

The University of Montana

Follow this and additional works at: https://scholarworks.umt.edu/etd

Let us know how access to this document benefits you.

\section{Recommended Citation}

Nelson, Greg C., "Maxillary canine/third premolar transposition in a prehistoric population from Santa Cruz Island California" (1989). Graduate Student Theses, Dissertations, \& Professional Papers. 7311.

https://scholarworks.umt.edu/etd/7311

This Thesis is brought to you for free and open access by the Graduate School at ScholarWorks at University of Montana. It has been accepted for inclusion in Graduate Student Theses, Dissertations, \& Professional Papers by an authorized administrator of ScholarWorks at University of Montana. For more information, please contact

scholarworks@mso.umt.edu. 


\section{COPYRIGHT ACT OF 1976}

THIS IS AN UNPUBLISHED MANUSCRIPT IN WHICH COPYRIGHT SUBSISTS. ANY FURTHER REPRINTING OF ITS CONTENTS MUST BE APPROVED BY THE AUTHOR,

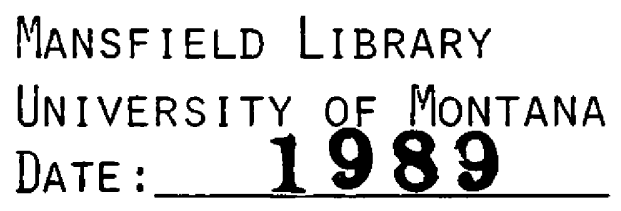



Maxillary Canine/Third Premolar Transposition

In A Prehistoric Population

From santa Cruz Island, California

by

Greg C. Nelson

B.A., University of California, Berkeley, 1981

Presented in partial fulfillment of the requirements

for the degree of

Master of Arts

University of Montana

1989

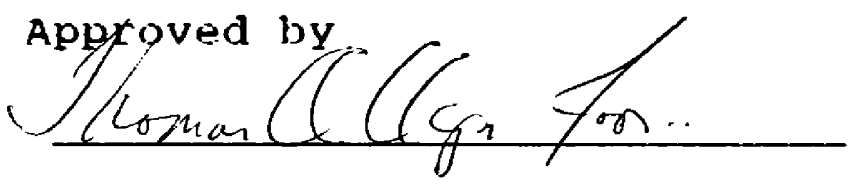

Chairman, Board of Examiners

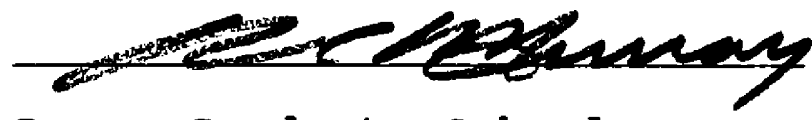

Dean, Graduate school

August 15,1989

Date 
UMI Number: EP38112

\section{All rights reserved}

\section{INFORMATION TO ALL USERS}

The quality of this reproduction is dependent upon the quality of the copy submitted.

In the unlikely event that the author did not send a complete manuscript and there are missing pages, these will be noted. Also, if material had to be removed, a note will indicate the deletion.

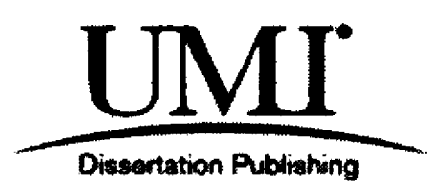

\section{UMI EP38112}

Published by ProQuest LLC (2013). Copyright in the Dissertation held by the Author.

Microform Edition (c) ProQuest LLC.

All rights reserved. This work is protected against unauthorized copying under Title 17, United States Code

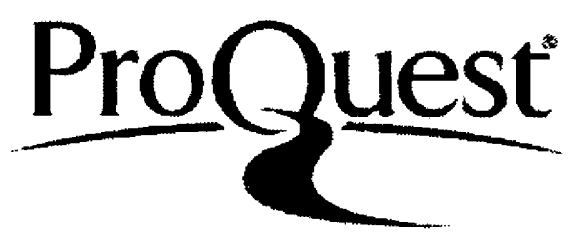

ProQuest LLC.

789 East Eisenhower Parkway

P.O. Box 1346

Ann Arbor, MI 48106 - 1346 
Maxillary canine/Third Premolar Transposition in a Prehistoric Population From Santa Cruz tsland, California

Director: Thomas A. Foor itF

Canine/Premolar transposition is vare in both historia and prehistoric Homo sapiens with modern rates being less than one tenth of one percent. This thesis reports and describes a prehistoric population from one site (scri-3) on santa cruz Island, California in which the rate of $C / P^{3}$ transposition is greater than eight percent, based on nine of 106 adult crania which exhibit the anomaly either uni or bilaterally. This high rate appears to be due to a genetic: anomaly which is temporally and geographically localized. As a means of investigating the etiology of this anomaly the location of the ranine root in adult crania was studied. Root location should indicate tooth bud origin, a factor likely to be under genetic control. In crania with normally erupted canines, the superior portion of the root averages $4.43 \mathrm{~mm}$ from alare while this distance is $8.96 \mathrm{~mm}$ for anomalous roots. This difference suggests that during ontogeny the tooth buds for the canine and premolar arose in the wrong (or reversed) places, causing the teeth to erupt anona $1011 \mathrm{~s} 1 \mathrm{y}$. 


\section{ACKNOWTEDGEMENTS}

I would like to thank my thesis committee of Drs. Sandy smith and Mark Taylor of the Department of Anthropology, Dr. Darshan Kang, Department of Geography, Dr. John suively D.D.S. and the chairman of the committee Dr. Thomas Foor for their help in this endeavor. Thanks also to Dr. Tim white of the University of california, Berkeley for allowing me access to the collections in the Lowie Museum, Dr. Fhillip walker of the University of California, santa Barbara for letting me examine the British Museum material on loan to him, and Dave Herrod of the Lowie Museum for granting me access to Dr. Olson's original notes.

special thanks to my wife charissa and my daughters Sarah and Greta for putting up with me during all this. 


\section{CONTENTS}

ABSTRACT

LIST OF TABLES

LIST OF FIGURES

vi

$\begin{array}{llr}\text { 1. INTRODUCTION } & 1\end{array}$

2. SANTA CRUZ ISLAND

$\begin{array}{ll}\text { Geography } & 7\end{array}$

$\begin{array}{ll}\text { Flora and Faunà } & 10\end{array}$

$\begin{array}{ll}\text { The People } & 11\end{array}$

Historic and Protohistoric: 11

$\begin{array}{ll}\text { Prehistoric: } & 13\end{array}$

Physical Anthropology

Genetic:s $\quad 14$

Alchaeology of site SCrI-3

$\begin{array}{lr}3 . & 23\end{array}$

Lowie Museum Specimens 26

British Museum specimens $\quad 37$

4. MATERIALS, METHOD, AND RESULTS 4.3

5. DISCUSSION AND CONCLUSION 48

$\begin{array}{ll}\text { Discussion } & 48\end{array}$

$\begin{array}{lr}\text { Conclusion } & 57\end{array}$

$\begin{array}{lr}\text { GLOSSARY } & 59\end{array}$

REFERENCES CITED $\quad 62$ 


\section{List of Tables}

$\begin{array}{ll}\text { 1. Classification of Artifacts with Burials. } & 18\end{array}$

2. Frequencies of Various objects per 100 Burials. 19

3. Descriptive table for the Nine Maxillae. 24

4. Directional Terms. 27

$\begin{array}{lr}\text { 5. Tooth Names. } & 29\end{array}$

6. Anomalous canine Root measurements. 46

7. Normal Canine Root Mésurements 47 


\section{LIST OF FIGURES}

1. BMNH \#SK 10120, Palatal View.

2. IM \#3999, Palatal View.

3. LM \#3963, Right and Left Lateral Views.

4. Map of California.

5. Map of Northern Channel Islands.

6. Map of Scri-3.

7. Reconstruction of Cultural Changes.

8. Comparative chronological sequences.

9. Numerical classification of Molar Wear.

10. Drawing of Maxilla, Directional Information.

11. Drawing of Maxilia Indicating Téth.

12. LM \#3960, Palatal View.

13. LM \#396.3, Palatal View.

14. LM \#3977, Palatal View.

15. LM \#3977, Left Laterál View.

16. LM \#3994, Palatal View.

17. BMNH \#SK 10009, Palatal View.

18. BMNH \#SK 10012, Palatal View.

19. BMNH \#SK 10037, Palatal View.

20. Derivation of canine Root Measurements.

21. Dixon and stewart's Interpretation of Transposition. 52

22. Tooth Eruption Chart. 


\section{CHAPTER 1}

\section{INTRODUCTION}

occasionally during the growth and development of the human dental arcade something goes awry, resulting in a dental anomaly of one kind or another. Among the rarest of these are transpositional anomalies, a condition in which the positions of two teeth within the arcade are reversed. According to Pindborg (1970) the occurrence rate for all types of transposition is 0.16 percent, with the teeth most frequently affected being the maxiliary canine and third premolar. Accounting for 40 percent of transpositions, C/P transposition occurs at a rate of 0.064 percent, making it extremely rare.

The purpose of this thesis is twofold: first to report and describe several cases of this type of anomaly that were found among a prehistoric population from site scri-3 on santa cruz Island, california; and second, to present evidence that the cause of this anomaly is genetic and not the result of pressure from other disturbances of the dental arcade as others (Pindborg, 1970; Dixom and stewart, 1976) have postilated. An analysis of canine root location is presented to show that the differential placement of normal and anomalous roots is real, siggesting that the buds for anomalous teeth originated in a transposed positivi and then proceeded to grow and erupt normally, but in the "wrilg" 
place. Following description of the teeth and the results of the distance analysis, the discussion will address not. only these specific instances of anomalous development but. also the genetic and physical development of the teeth and paraoral structures, and how they also point to a genetic: origin for transpositional anomalies.

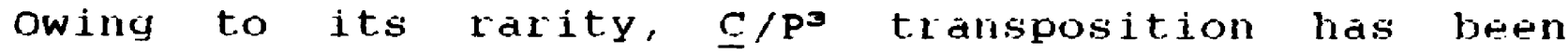
lightly touched upon previously and is largely unrecorded in prehistoric skeletal material. Those works that do mention transposition (Dixon and stewart, 1976; kerr and Ash, 1978) generally deal with it superficially, lump it with such things as supernumary teeth, or list it under the broad heading of developmental disturbances.

At first it appeared that the anomaly was related to or caused by other developmental disturbances as several of the specimens evidence dental crowding in various degrees and one (BMNT \#SK 10120, Fig. 1) retains its Rdiz (right deciduous second incisor, see chapter 3 for explanation). However, upon closer examination it became apparent the transposition was caused by something other than pressure from other disturbances. First, one cranium, Lowie specimen \#3999 (Fig. 2), shows no evidence of any disturbance besides the transposition, and second, the location of the canine roots differs between those that erupted normally and those that did not. Grossly, the roots of the transposed canines are obviously farther away from the nasal opening (Fig. 3 ). 


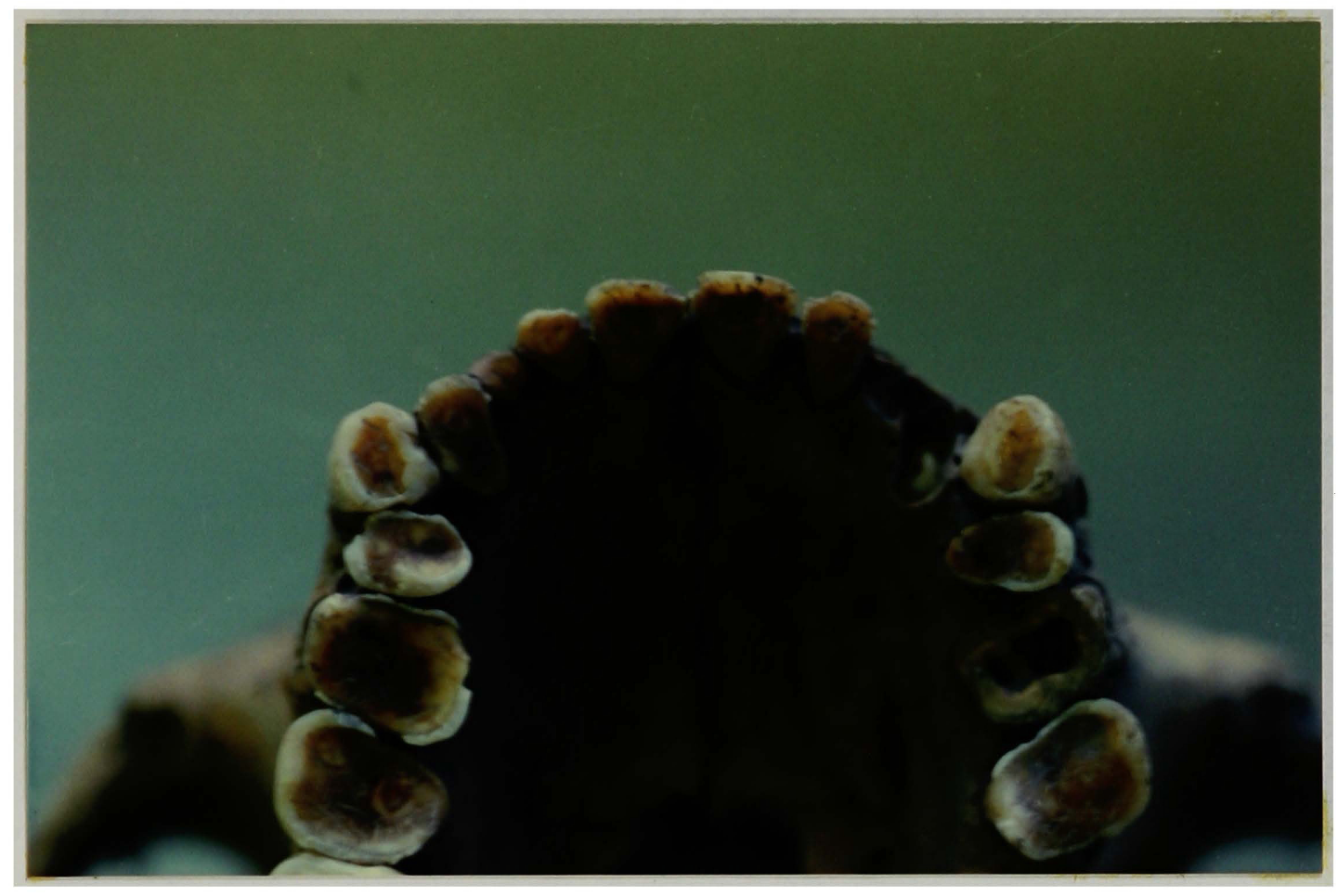

Figure 1. Palatal view of British Museum specimen SK10120. Note $R d i \geq$ retention and "pinching" of transposed canines. 


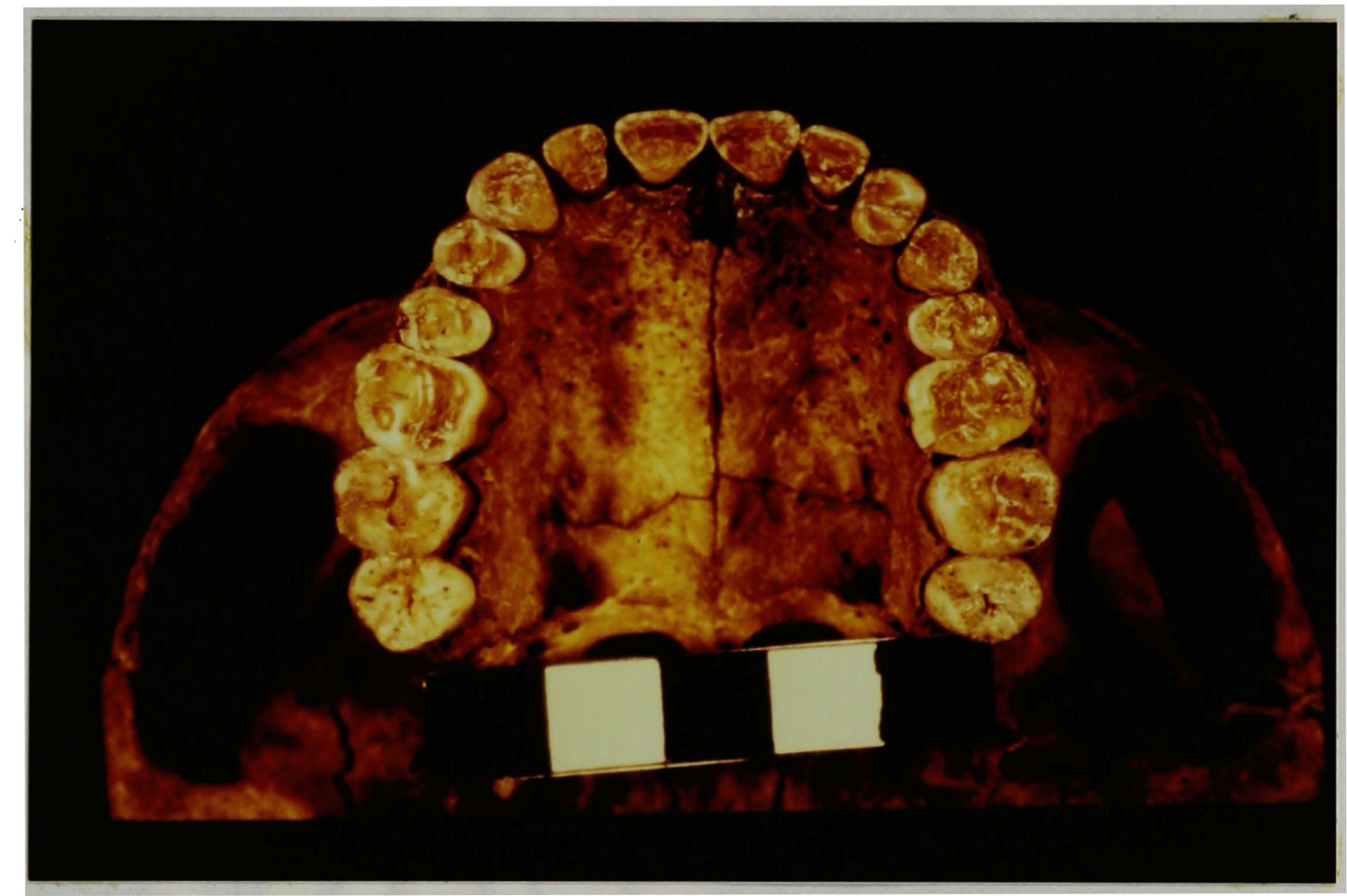

Figure 2. Palatal view of Lowie Museum specimen 3999. Transposition is on the left side only. Scale in $\mathrm{cm}$. 

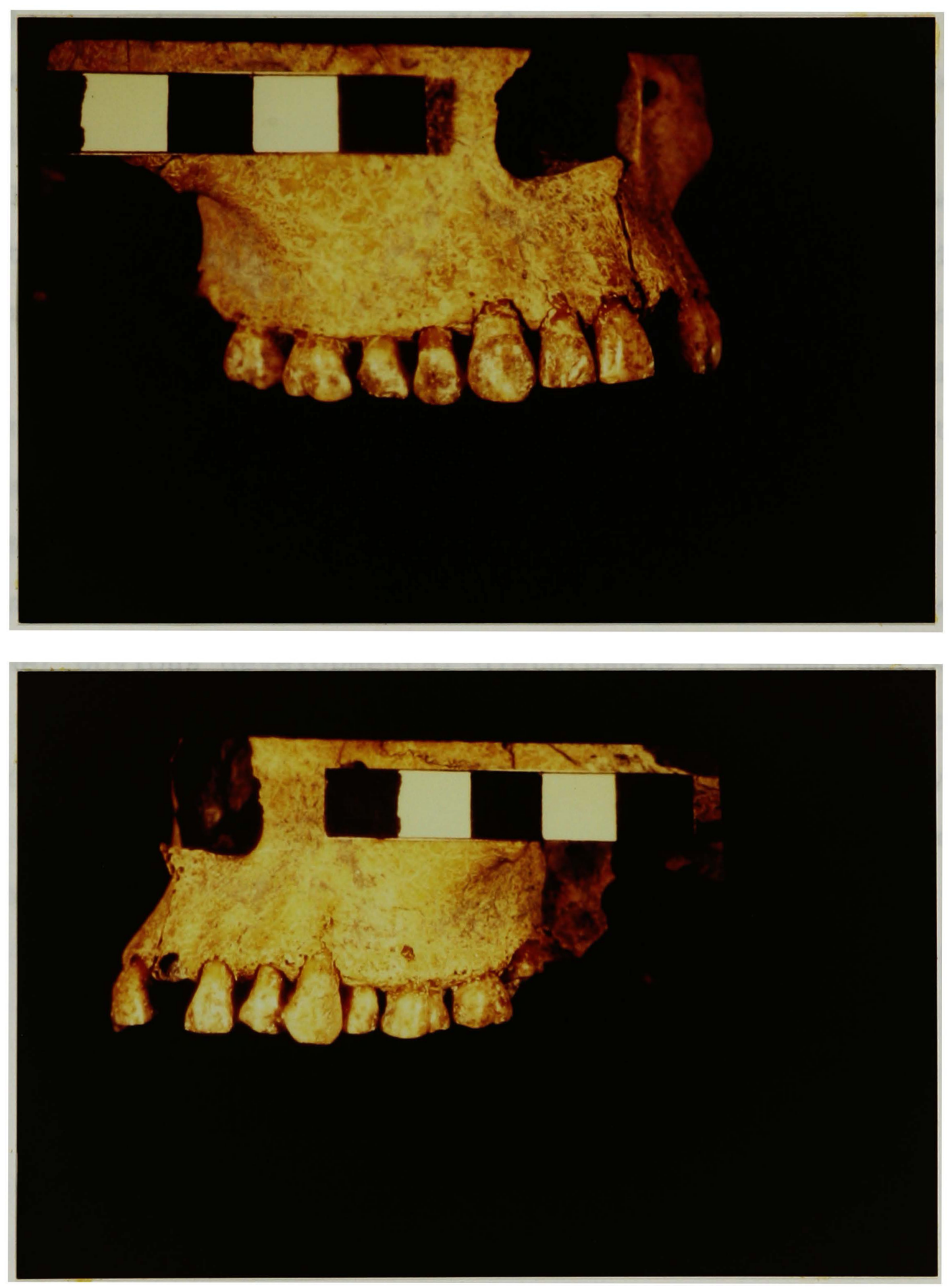

Figure 3. Anterio-lateral views of right (top) and left (bottom) maxillae of Lowie Museum specimen 3963. Note that the left canine root is approximately twice as far from the nasal opening than is the root for the right canine. Scale in cm. 
of course, this latter state would be expected since the anomalous canines occupy a different location within the arcade. However, the roots are relatively straight as in normal teeth. A straight root is important becallse if the anomaly were caused by another developmental disturbance then the tooth bud for the canines would have originated in a normal position and, after growth had begun, the tooth would have been moved, via the forces involved in crowding or retention, to its anomalous position, causing deformation of the root.

Both of these points suggest other explanations for the origins of the anomaly. If the transposition appears with no other obvious developmental disturbance it seems unlikely that its source is related to disturbance of later tooth formation or eruption. Rather, the reason for it may be found earlier in the development of the maxilla, most probably at the time when the cells that would become the tooth buds were differentiating. 
CHAPTER 2

\section{Santa Cruz Island}

GEOGRAPHY

Santa cruz Island is the largest and most diverse, both geographically and ecologically, of the channel Islands chain (see Maps; Figs. 4, 5). It is approximately 24 miles long, east to west, and varies from two to seven miles in breadth; creating an area of about 96 square miles. The Island topography consists of two east-west running mountain ranges which basically parallel the northern and southern coasts. The northern range reaches an altitude of c.2,400 feet while the southern range goes to $0.1,500$ feet. The mountain ranges are separated by a large central valley.

The coastline is fairly variable with cliffs predominating along much of the north and south coasts while the southwestern portion of the coast comsists of broad stretches of sandy beach. Around the island are also many sheltered coves which can be used as anchorages. Fresh water can be found throughout the island in the form of seeps and springs, many of which are perennial. There are presently enough year round water sources that during aboriginal times no point on the island was probably very far from potable water (Glassow, 1977). 


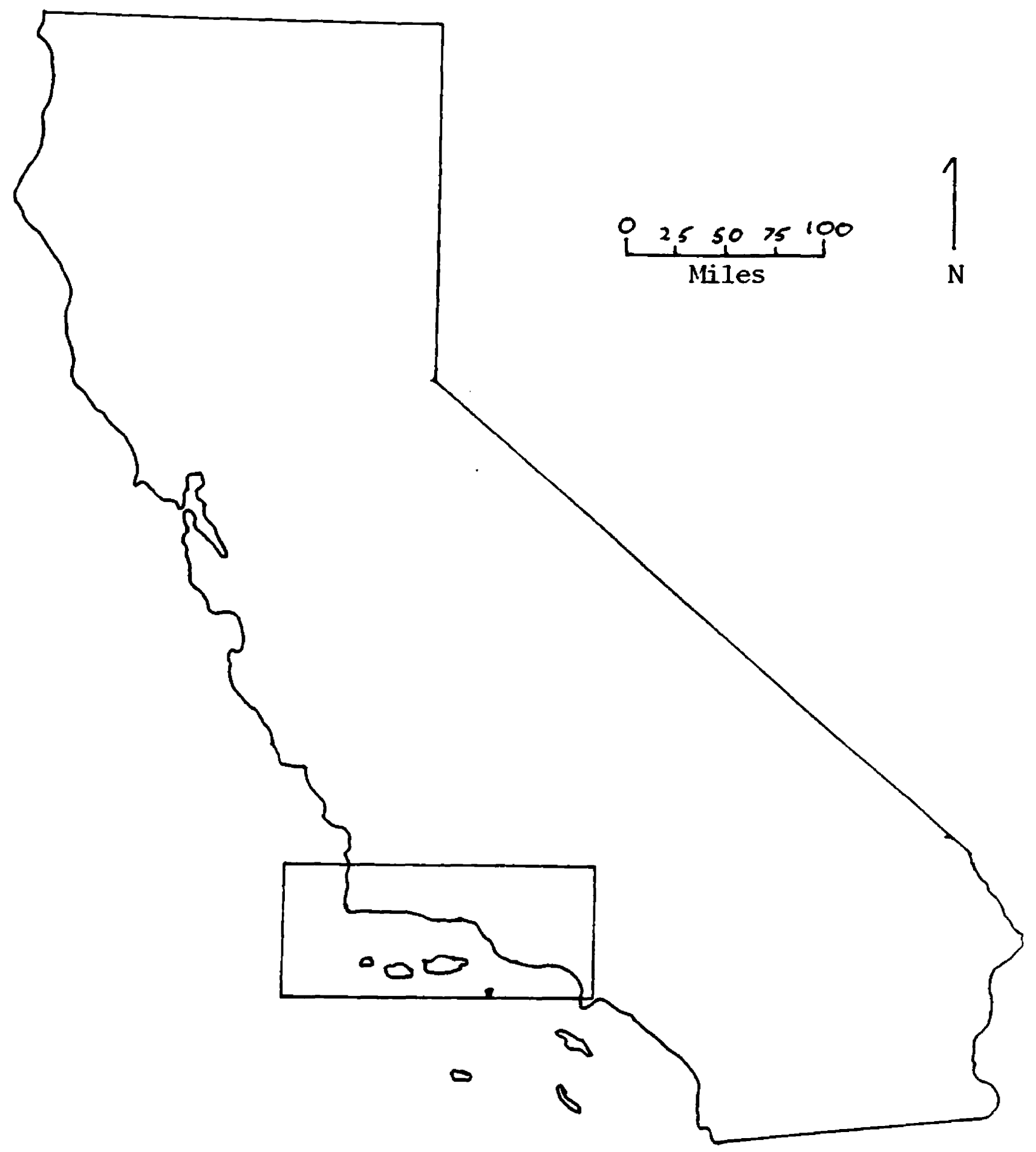

Figure 4.

California with the Northern Channel Islands (Fig. 5) Highlighted. 


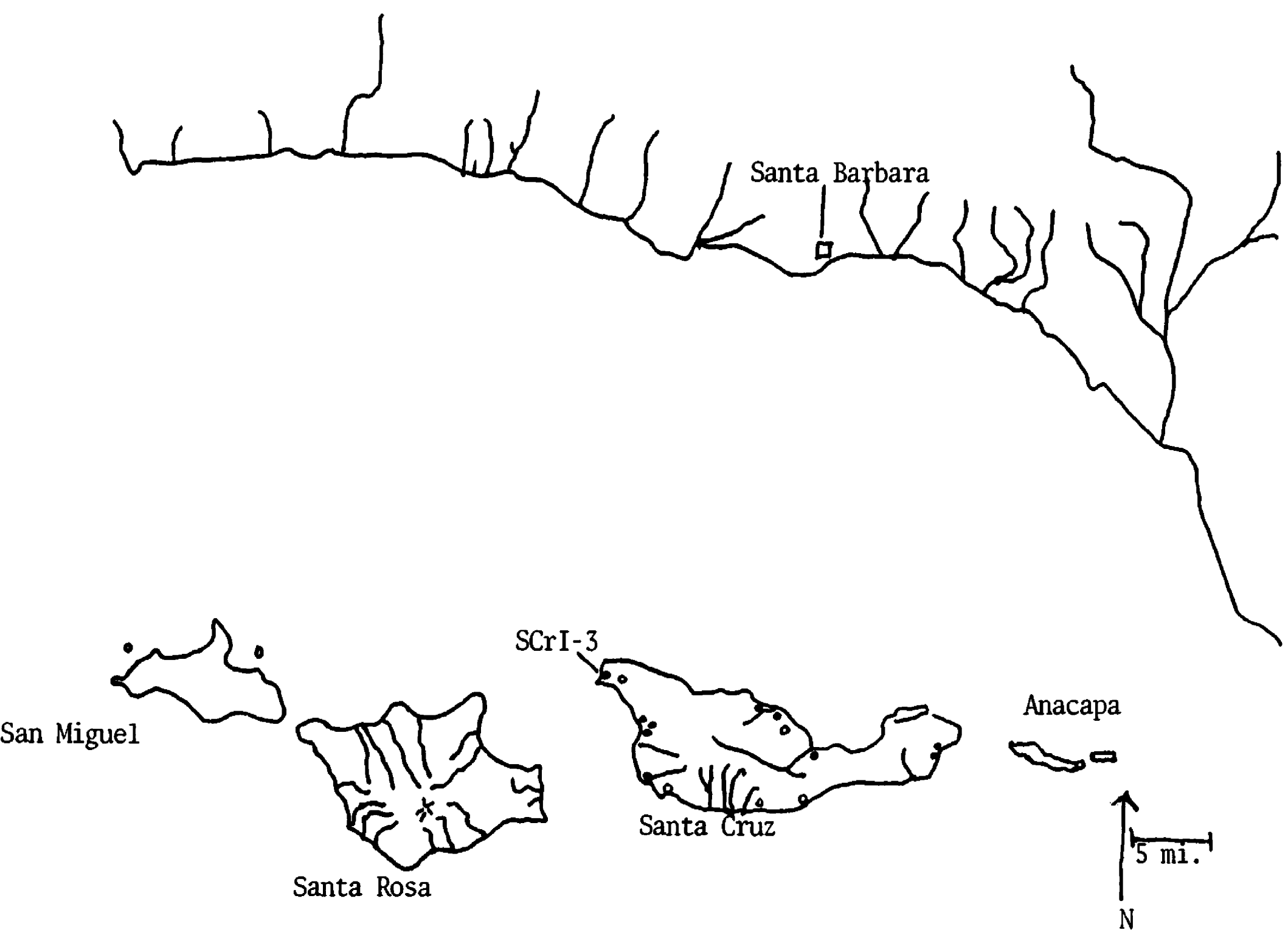

Figure 5. i.
Northern Channel Islands. 


\section{FLORA AND FAUNA}

The basic island flora is one of grassland broken by groves of live oak (Quercus spp.) on gently sloping alluvial terraces. The flood plain of the central valley has intermitent stands of mulefat (Baccharis vimenea) and willow (salix spp.). The north slopes of both the northern and southern mountain ranges have groves of island pine ( individuals or clumps of toyon (Herteromeles arbutifolia), manzanita (Arctostaphylos insularis), and catalina cherry (Prunus lyonii). Deep canyons frequently have dense stands of various species of oak which are thick enough to create a canopy.

The faunal assemblaye of santa cruz Island includes only three indigenous species of mammal, excepting several species of bát, and one introduced mouse. vrocyon littoralis, the island fox, is quite prevalent as is the déer mouse, Peromyscus maniculatus. Less prevalent, though by no means rare, is spiologale gracilis, the island or spotted skunk. Reithrodontomys megalotis, a species of harvest mouse, was introduced in historic times and can be found throughout the island.

Several species of shellfish are found within the intertidal zone surrounding the island. Mussels lmytilus californianus) predominate on the rocky shores around the 
island. Many areas, esperially along the south coast are excellent habitat for black (Haliotis aracherodi) and red (H. rufescens) abalone. Kelp beds can be found at many places around the island and not only serve as habitat for rock/kelp fish but also attract harbor seals (Phoca vitulina) and California sea lions (zalophus californiamus) which feed on the fish (Glassow, 1977).

\section{THE PEOPLE}

Historic and protohistoric

Aboriginally the northern channel Islands (santa cruz, Santa Rosa, San Miguel and Anacapa) and the Mainland coast were occupied by peoples speaking several dialects of the Chumash language, a member of the Hokan linguistic family. The area occupied by the chumash was summed up by Kroeber as follows:

They held the three northern large islands of the Santa Barbara archipelago--Anacapa does not appear to have been inhabited permanently. They clustered thickly along the calm shore from Malibu canyon westward to point concepcion and from there extended northward along the more boisterous and chillier coast as far as Estero Bay. Inland, in general, they reached to the range that divides the direct ocean drainage from that of the great valley; except that in the west their frontier was the watershed between the salinas and the santa Maria and short coast streams; and in the east, some small fragments had spilled into part of the most southerly drainage of the San Joaquin-Kern system. The carrizo plains are doubtful as between chumash and salinan and may not have contained any permanent villages (Kroeber, 1925, pp.550-551). 
According to Heizer and whipple (1971) and Glassow (1977) the Chumash 1 ived on santa cruz Island year romol and spoke a separate dialect from those who lived on the mainland. Apparently the Island chumash were sociopolitically autonomous and to a degree ethnically distinct from the Mainland Chumash.

Although in many ways different from the people who lived on the mainland, the subsistence patterns of the santa cruz Islanders were similar. Except for large terrestrial mammals, which did not live on the island, both groups of native peoples exploited the marine resources of shellfish, fish, and mammals as well as terrestrial food sources such as acorn, coastal sage (Artenisia californica), and, on the island only, the bulb of the perenmial blue dick lBrodiaed spp.) (Glassow, 1977$)$.

It is apparent that well established trade networks existed between the island and the mainland. In return for shell beads and bladelets, made from local chert, the Islanders received meat and vegetal food stufes from people on the mainland. The trading network was so well established that some native islanders moved to and lived permanently on the mainland, apparently acting as intermediaries (king, 1976). 
Prehistoric:

Physical Anthropology

The physical anthropology of the prehistoric: inhabitants of the channel Islands has not been extensively studied. Recently however, Phillip walker of the university of California at santa Barbara and his co-workers have undertaken several investigations in this area. One of these (walker, 1986 ) deals with scri-3 and concerns the high rate of porotic hyperostosis, specifically cribra orbitalia, that is found in skeletal samples from santa cruz and santa Rosa Islands and the mainland. Approximately 17.5 percent of scri-3 crania, from the same British Museum sample used in this study, exhibit cribra orbitalia. This indicates a high rate of anemia most probably brought on by exposure to contaminated drinking water, and the resulting diarrheal infections which were manifested primarily in young children. In conjunction with contaminated water other Eactors which may have contributed to anemia include ingestion of fish and mammal-borne parasites, prolonged breast feeding, and weanling diarrhea (walker, 1986).

other studies by walker include investigating dental attrition (walker, 1978) and dental caries rates through time (walker and Evlandson, 1986) as well as nitrogen and carbon isotope ratios in bone collagen (walker and DeNiro, 1986). The point of all three of these studies was to 
elucidate information concerning the diet of the prehistoric: inhabitants of the santa Barbara Channel area and its change over time.

Genetias

During the Early period occupations at scri-3 it is apparent that the island population was more isolated from those of the mainland and other islands than it was during the protohistoric and historic periods (walker, 1978; King, 1981; Morrato: 1984). The ladk of a known sea going vessel in the archaeological record (the plank canoe does not appear until about 1500 B.P. (walker, 1978)) would indicate that contact between the Islanders and other populations was probably infrequent. If little contact with other peoples was indeed the case on santa cruz Island then it is probable that the island held a population of relatively finite size. In discussing models of population genetics of isolate populations cavalit-sforza and Bodmer (1971, p.460) note that "a finite population is always subject to some degree of inbreeding because of its finite size". Where there is inbreeding the chance of a recessive gene being expressed increases as in a case of $C^{3}$ transposition discussed by Feichtinger et al. (1977) in which three of eight siblings of a second cousin marriage exhibit the anomaly. 
One factor that may increase the chances of inbresding in an isolated population is marriage practice. Although the archaeology of scrI-3 cannot tell us much about marriage practices of the time, indications are that societal changes were few and it appears that there was approximately 7000 years of in situ development (king, 1981). If this is the case then extrapolation backward from what is known about the chumash is not as tenuous as might be expected. Protohistorically the inhabitants of santa cruz Island lived in villages made up of patrilineal descent groups that were virilocal. It is apparent that marriage rules consisted of lineage exogamy combined with village endogamy (Landberg, 1965). Although the island area is relatively small, and therefore, exogamy might be expected, it appears there was intervillage animosity which led to frequent warfare. a situation which would preclude the practice of exogamy. Both Cavalii-sforza and Bodmer (1971) and Reid (1973) indicate endogamy is an important factor in inbresding. When combined with finite population size endogamy increases the probability of inbreeding to the degree that nondeleterious genetic mutations may become common.

A11 of these factors indicate that the peoples of santa cruz Island were a genetic isolate. Genetic isolation is a prime environment for the appearance of a recessive land non-deleterious) trait such as $\underline{C} / P^{3}$ transposition, which is, in itself, an indication of this isolation. 
The history of archaeological research on santa cruz Island is long and begins with excavations that took place during May and June of 1875 under the direction of Paul Schumacher (Schumacher, 1877; Glassow, 1977). Although many sites on the island had been dug by both professionals and amateurs, scri-3 at Forney's cove on the west end of the Island, was not excavated until 1927. During the summers of 1927 and 1928 crews under the direction of Ronald olson of the University of california, Berkeley excavated 16 coastal sites around the island (see map, Fig, 5) usually spending a week or more at each (Glassow, 1977; Morrato, 1984). SCrI-3 was excavated during the period of July 12 to July 18,1927 (Olson, n.d.; Glassow, 1977). Glassow (1977, p.111) states that 102 single and multiple burials were recovered while $01 \operatorname{son}(1930$ Table 4, p.14; Table 1, this paper) notes 107 burials. During the week at scri-3 olson excavated 17 pits in the cemetery area and noted 20 house pits lsee map, Fig. 6). Following these excavations the welcom-Moodie expedition worked at scri-3 during september 1932 . These excavations were much less exact and the only written records are a short (one and one-half page) paper: an article in the Los Angeles Times sunday Magazine, and field notes. The excavations recovered 130 burials, all but 13 of which are unprovenienced, and assorted artifacts (Glassow, 


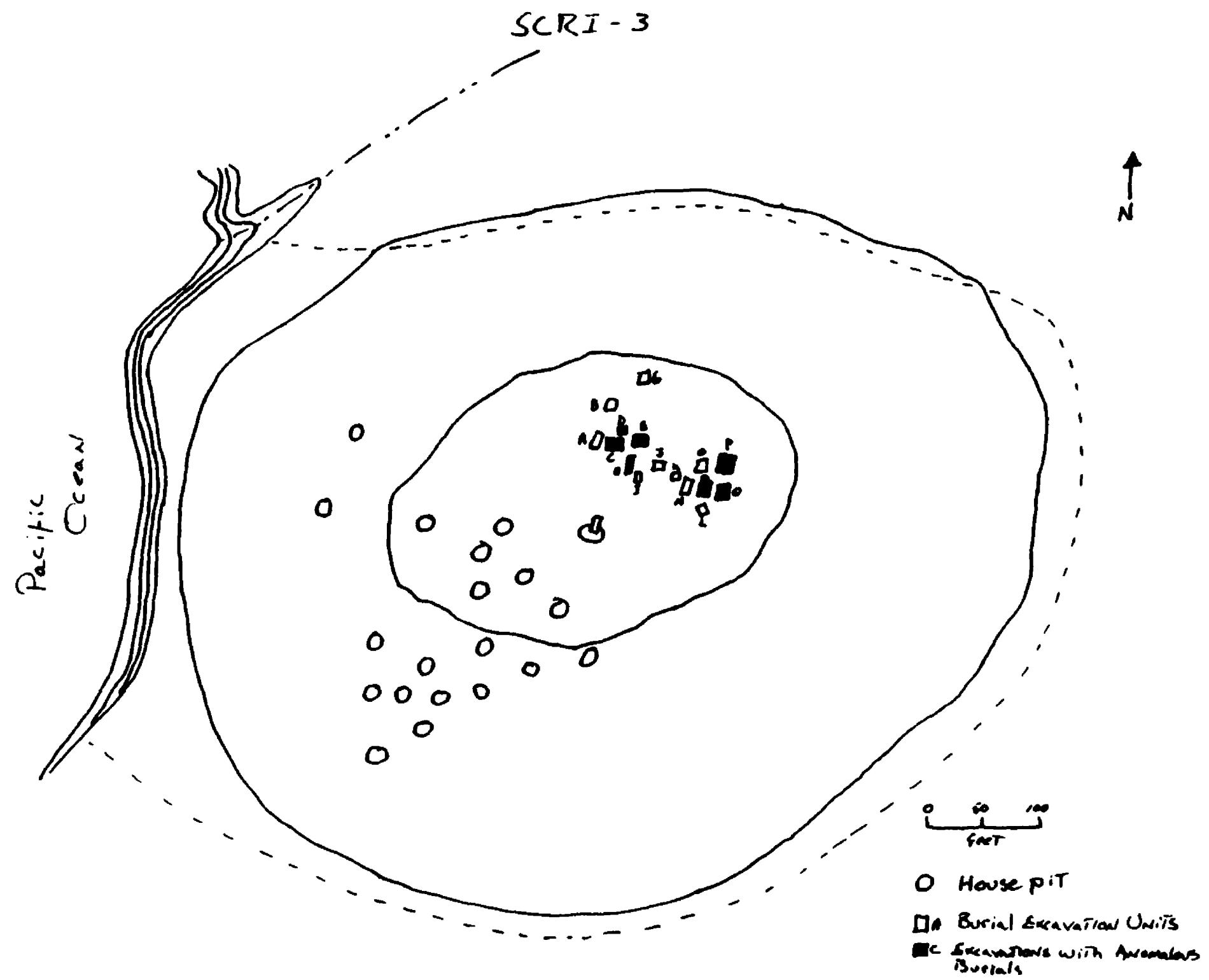

Figure 6. Map of SCrI-3 (Adapted from Hoover, 1971). 
Table 1

Classification of Artifacts with Burials

\begin{tabular}{|c|c|c|c|c|c|c|c|c|c|c|c|c|c|c|c|}
\hline \multirow{2}{*}{$\begin{array}{l}\text { Tentative period } \\
\text { Site number }\end{array}$} & \multicolumn{2}{|c|}{$\begin{array}{c}\text { Early } \\
\text { Melnland }\end{array}$} & \multicolumn{2}{|c|}{$\begin{array}{r}\text { Inter- } \\
\text { mediate } \\
\text { Mainland } \\
\end{array}$} & \multicolumn{4}{|c|}{ Early Island } & \multicolumn{6}{|c|}{$\begin{array}{l}\text { Intermediate } \\
\text { to Late Ioland }\end{array}$} & \multirow{2}{*}{$\begin{array}{c}\begin{array}{c}\text { Late } \\
M \cdot l a n d\end{array} \\
1\end{array}$} \\
\hline & 2 & 11 & 1 & 1 & 159 & 162 & 3 & 83 & 83 & 81 & 100 & 82 & 135 & 138 & \\
\hline Cemetery or pit numbers & - & - & 1 & 2 & - & - & - & 2 & 1 & - & - & - & - & - & 3 \\
\hline Total burials & 49 & 4 & 26 & 37 & 19 & 25 & 107 & 72 & 88 & 5 & 161 & 9 & 19 & 48 & 56 \\
\hline
\end{tabular}


Table 2

Prequenoles of Varlous Objects per 100 Burlals

\begin{tabular}{|c|c|c|c|c|c|c|c|c|c|c|c|c|c|}
\hline S1 te Number. & 2 & 11 & 1 & 1 & 159 & 162 & 3 & 83 & 83 & 100 & 135 & 138 & 1 \\
\hline Cemetary Number & & & 1 & 2 & & & & 2 & \multicolumn{4}{|l|}{1} & 3 \\
\hline Tentat1ve Period & \multicolumn{2}{|c|}{$\begin{array}{c}\text { Early } \\
\text { Mainland }\end{array}$} & \multicolumn{2}{|c|}{$\begin{array}{l}\text { Intermediate } \\
\text { Meinland }\end{array}$} & \multicolumn{4}{|c|}{ Early IBland } & \multicolumn{4}{|c|}{$\begin{array}{l}\text { Intermediate } \\
\text { to Late Island }\end{array}$} & $\begin{array}{l}\text { Late } \\
\text { M'land }\end{array}$ \\
\hline Number of Burialo & 49 & 4 & 26 & 37 & 19 & 25 & 107 & 72 & 88 & 161 & 19 & 48 & 56 \\
\hline Morters and pestles & 58 & 150 & 76 & 16 & 25 & 28 & 17 & 18 & 14 & 6 & 15 & 4 & 31 \\
\hline Metates and mullers & 2 & 200 & 8 & 0 & $\mathbf{0}$ & 0 & 0 & 1 & 1 & 1 & 0 & 0 & 0 \\
\hline Pseudo-metates & 2 & 0 & 0 & 0 & $\mathbf{0}$ & 0 & 2 & 0 & 4 & 2 & 0 & 0 & 0 \\
\hline Dr1118 & 0 & 0 & 4 & 0 & 0 & 16 & 2 & 0 & 16 & 8 & 5 & 14 & 4 \\
\hline Perforated atones & 0 & 0 & 0 & 0 & 10 & 56 & 19 & 27 & 10 & 7 & 5 & 10 & 0 \\
\hline Charmetones & 18 & 0 & 0 & 0 & 20 & 0 & 1 & 0 & 0 & 0 & 0 & 0 & 0 \\
\hline Steat1 te ollas and pans & 0 & 0 & 20 & 0 & 0 & $\mathbf{0}$ & $\mathbf{0}$ & 0 & 0 & 0 & 10 & 8 & 36 \\
\hline Stone pipes & 18 & 0 & 0 & 0 & 5 & 0 & 0 & 3 & 2 & 2 & 5 & 2 & 10 \\
\hline C1rcular hooks & 0 & 0 & 4 & 4 & 0 & 0 & 0 & 0 & 46 & 33 & 0 & 6 & 5 \\
\hline Straleht hooks & 0 & 0 & 0 & 0 & 10 & 4 & 10 & 0 & 14 & 3 & 0 & 2 & 2 \\
\hline Bone pendante & 0 & $\mathbf{0}$ & $\mathbf{0}$ & 2 & 5 & 4 & 2 & 25 & 0 & 0 & 0 & 0 & 0 \\
\hline Inlay work & 0 & 0 & 28 & 16 & 0 & 0 & 5 & 0 & 5 & 3 & 0 & 0 & 2 \\
\hline
\end{tabular}


$1977)$

The types and frequencies of artifacts recovered by olson at SCrI-3 are reprinted here in tables 1 and 2 . In Olson's original 1930 paper they were designated Tables 4 and 5 .

The dating of scri-3 was, up until the 1 ate $1970^{\prime} s$, based on artifact type. olson (1930) by using artifact Erequencies built a sequence of aulural changes that delineated Early, Intermediate, and Late Mainland periods as well as Early and Late Island periods (Fig. 7). On both the islands and mainland the Late periods begin with the appearance of European artifacts. Expanding on olson's work on Santa cruz Island, Hoover (1971) combined it with other workers to create a comparative chronology for the santa Barbara region (Fig. 8). This chronology placed the Early Island period of olson, to which sCrI-3 belongs, as lying between aporoximately 3500 and 4200 B.P., although walker (1986) notes a time range of 5000 to 4000 B.P. for the site. 


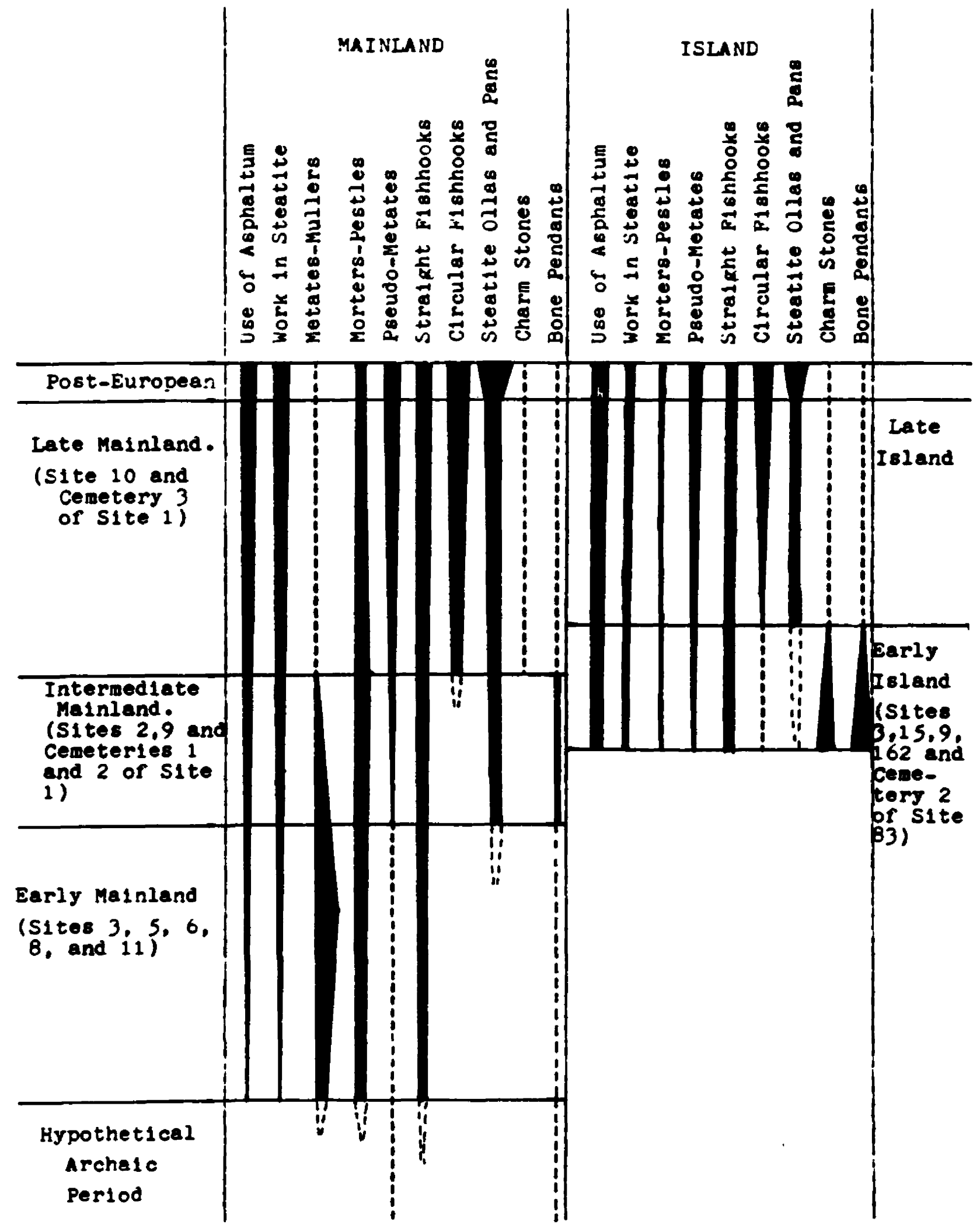

Figure 7.

Reconstruction of cultural changes (adapted from 01son, 1930). 


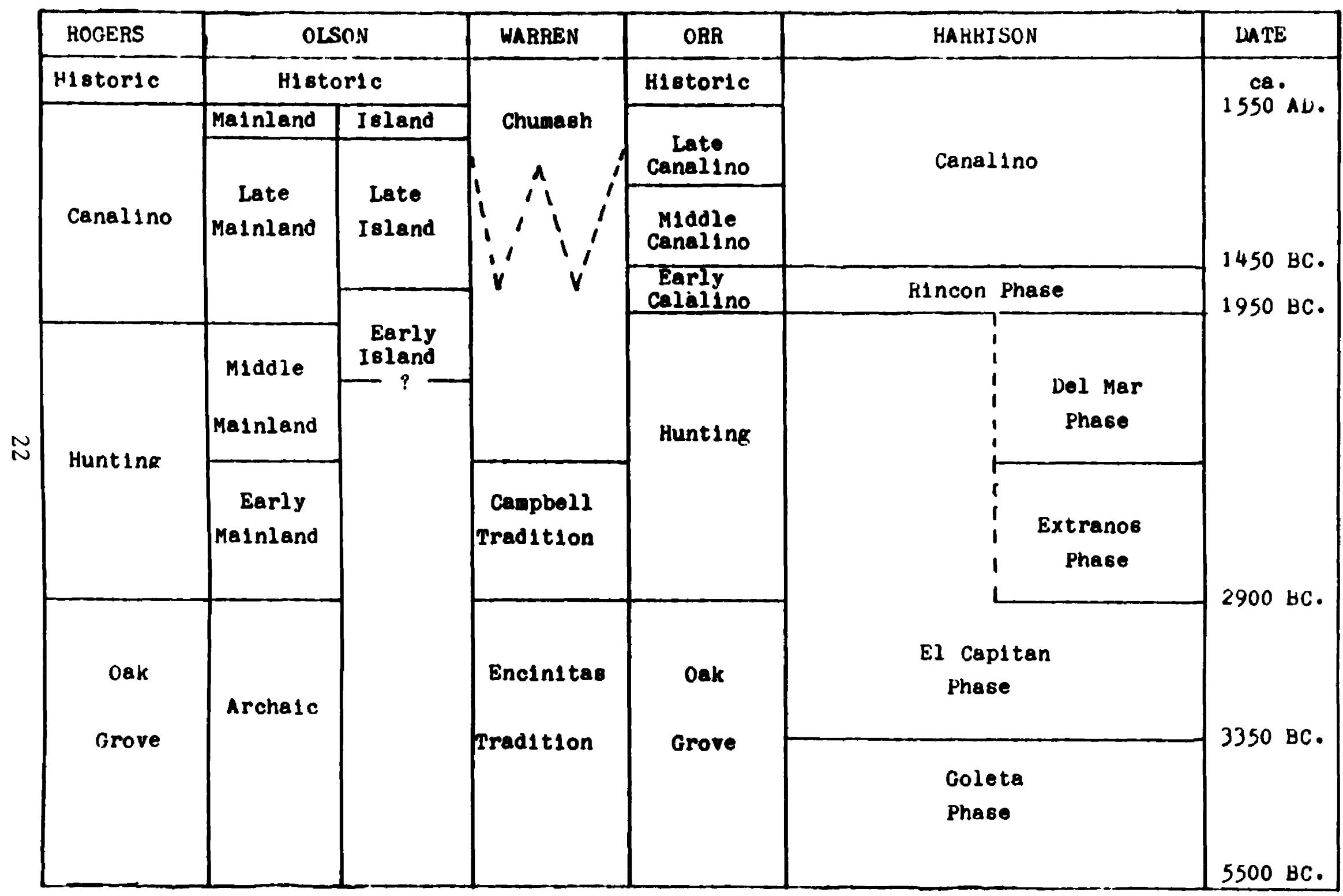

Figure 8 .

Comaprative chronological sequences of the Santa Barbara Channel area (adapted from Hoover, 1971). 
CHAPTER 3

\section{Descriptions}

This chapter contains descriptions of the nine maxillae in which the transposition occurs (see also Tablo 3) as well as information concerning anthropological nomenciature used for the dentition.

For the five (of 50) specimens from the Lowie museum, in which the entire skeletons were available, sex was determined by the sub-pubic angle, the sciatic notch, and the general robusticity of the skull. Age was estimated using epiphyseal fusion, cranial suture closure, and dental wear and attrition. With the 56 British Museum specimens, of which four are anomalous, sex and age are based on features of the skull and dentition as only the crania were present. All tooth wear numbers are based on Brothwell (see Fig. 9, reprinted from Brothwe11, 1981 Fig. 3.9).

Referential nomenciature for the human dentition, as used in anthropology, is based on the primitive primate condition which consisted of 3 incisors, 1 canine, 4 premolars, and 3 molars $(3-1-4-3)$. The abbreviated notations used by most physical anthropologists will be used here. In this system the first letter of the tooth name is presented in upper case and, in all cases except for the canine, is followed by a super or subscripted number which velates to its order, mesial to distal, among its fellows. 
Table 3. Data for the nine specimens that is not included in the descriptions

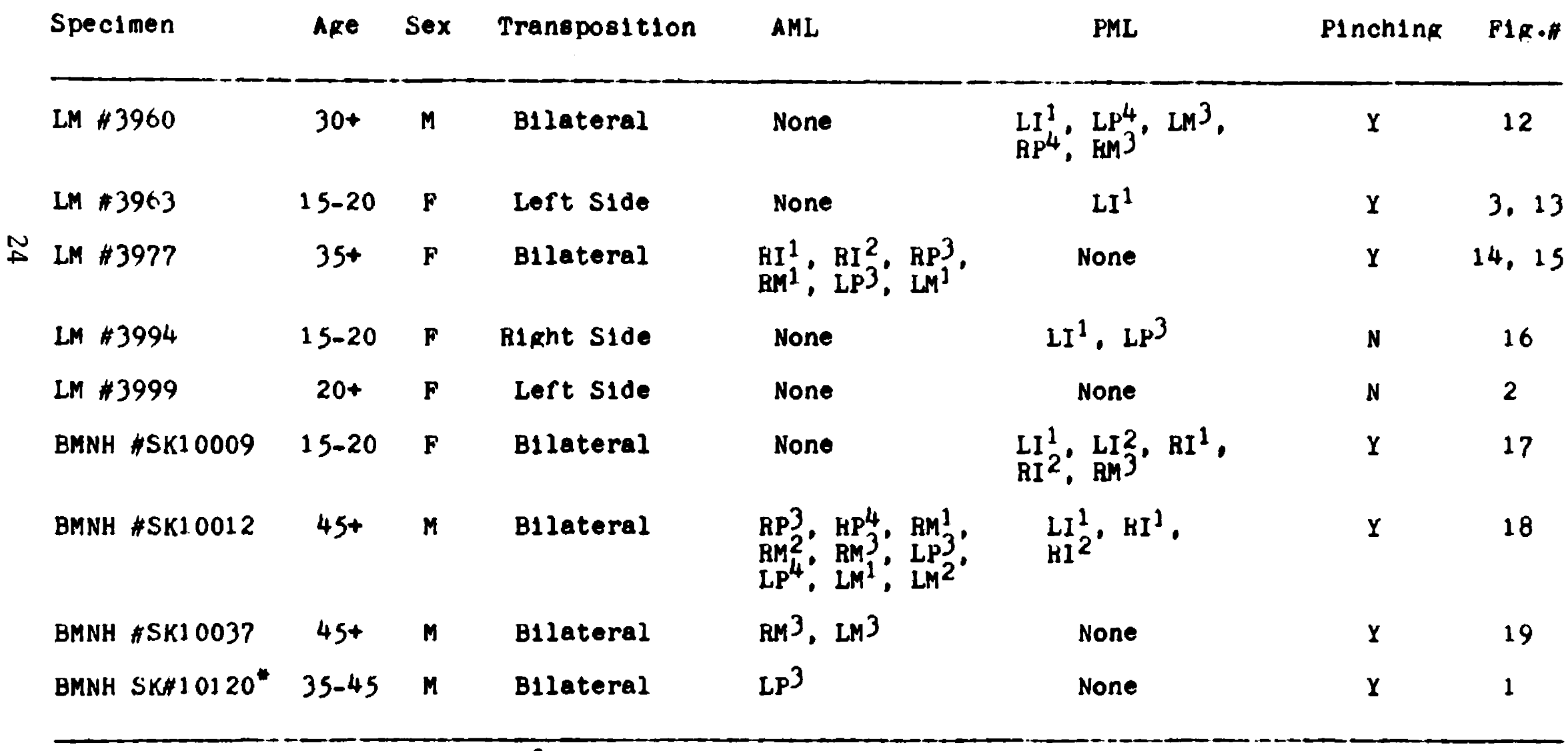

- BMNH SK\#10120 retains 1 t8 $\mathrm{Rd}^{2}$. 


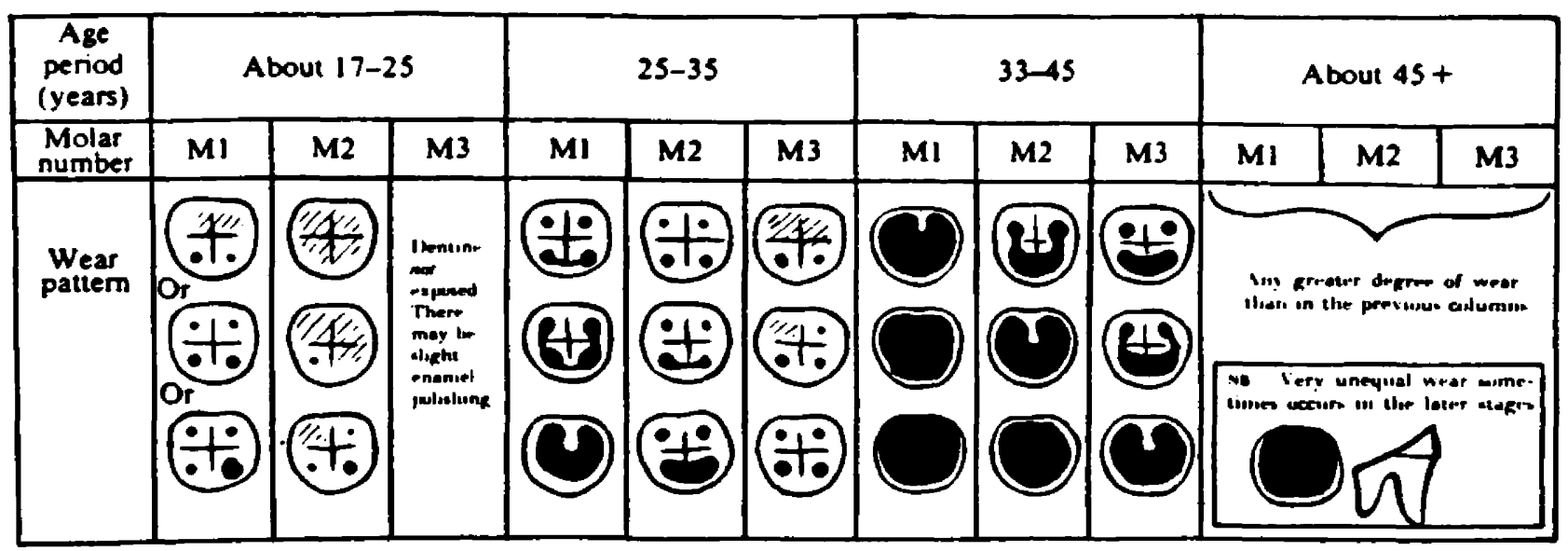

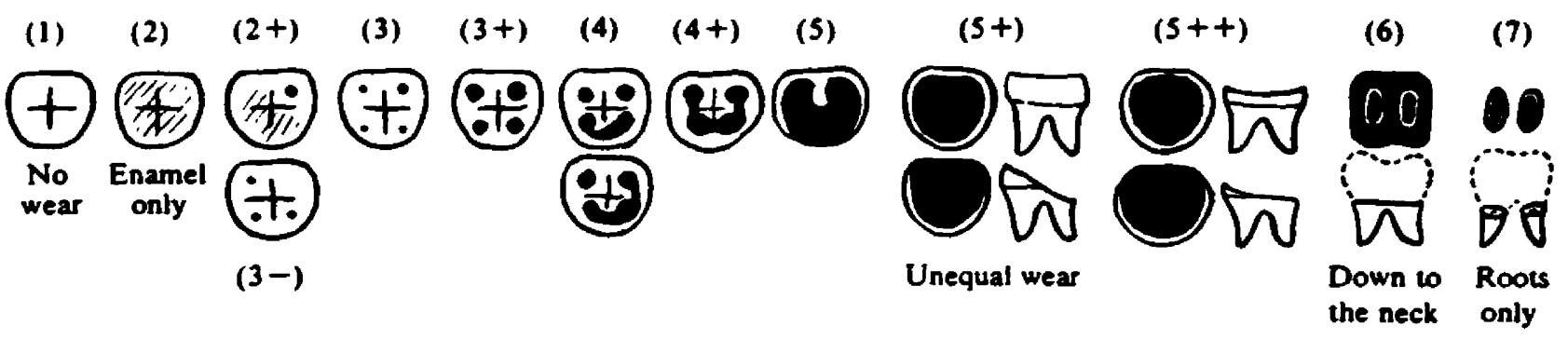

Figure 9.

Numerical classification of molar wear derived from Medieval English dentition. (adapted from Brothwell, 1981 ) 
superscripting designates upper, or maxiliary, teeth while subscripting designates lower, or mandibular, teeth. As only one-half of the arcade is described using these terms the tooth designation is usually preceded by an upper case R or L which indicates right or left. Déciduous teeth are indicated by using lower case letters. That the modern human dental formula of 2-1-2-3 varies from the primitive formula noted above can be explained by the fact that, through evolutionary changes, Homo sapiens no longer retains its $I^{3}, I_{3}, P^{1}, P_{2}, P^{2}$, or $P_{2}$. See Tables 4 and 5 , and Figures 10 and 11 for further clarification.

\section{DESCRIPTIONS}

LOWIE SPECIMEN 3960 (FIg. 12)

In this specimen the condition of the dentition is poor. There are fairly extensive interproximal caries between the $P^{3} s$ and canines and on the $M^{3} s$. There is no evidence of crowding. In the area of the transposition. the sockets for the $P^{4 \prime} s$ are small and relatively shallow. The roots of the $P^{3}$ 's are not well developed and appear t.o be short. The canine roots are massive, long, slightly curved, and exposed. Although the roots of the $P$ is are underdeveloped, what can be seen of the crowns, although carious, appear to be normal. 
Table 4.

Terms used to denote direction.

see also figure 10 .

Buccal: Toward the buccal or cheek cavity of the mouth. Used for premolars, molars, and occasionally canines. Opposite of lingual.

Labial: Toward the lips. Used for orientation of the incisors and canines. opposite of 1 ingual.

Lingual: Toward the tongue. Opposite of buccal and 1 abial.

Mesial: Toward the front of the mouth or the point where the median (mid-sagittal) plane bisects the maxilla between the central incisors.

Distal: Toward the back of the mouth or away from the median plane. 


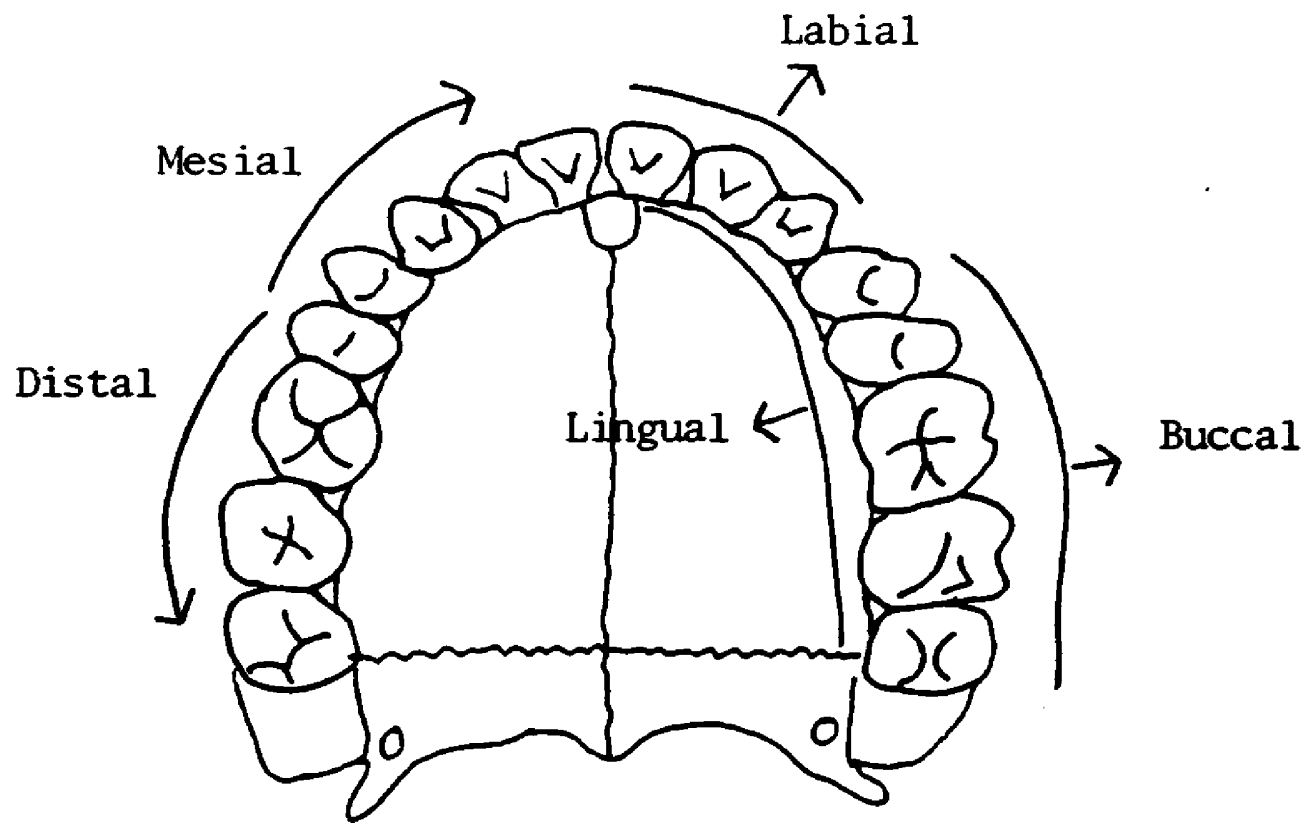

Figure 10

Diagram of normal human maxilla with directions noted. 
Table 5 .

Tooth names and abbreviations for maxillary teeth. see also figure 11.

Abbreviations

Tooth Name

\begin{tabular}{ll}
\hline$I^{2}$ & Central Incisor \\
\hline C & Lateral Incisor \\
$\mathrm{P}^{3}$ & Canine \\
$\mathrm{P}^{4}$ & Third Premolar \\
$\mathrm{M}^{2}$ & Fourth Premolar \\
$\mathrm{M}^{2}$ & First Molar \\
$\mathrm{M}^{3}$ & Second Molar \\
\hline
\end{tabular}




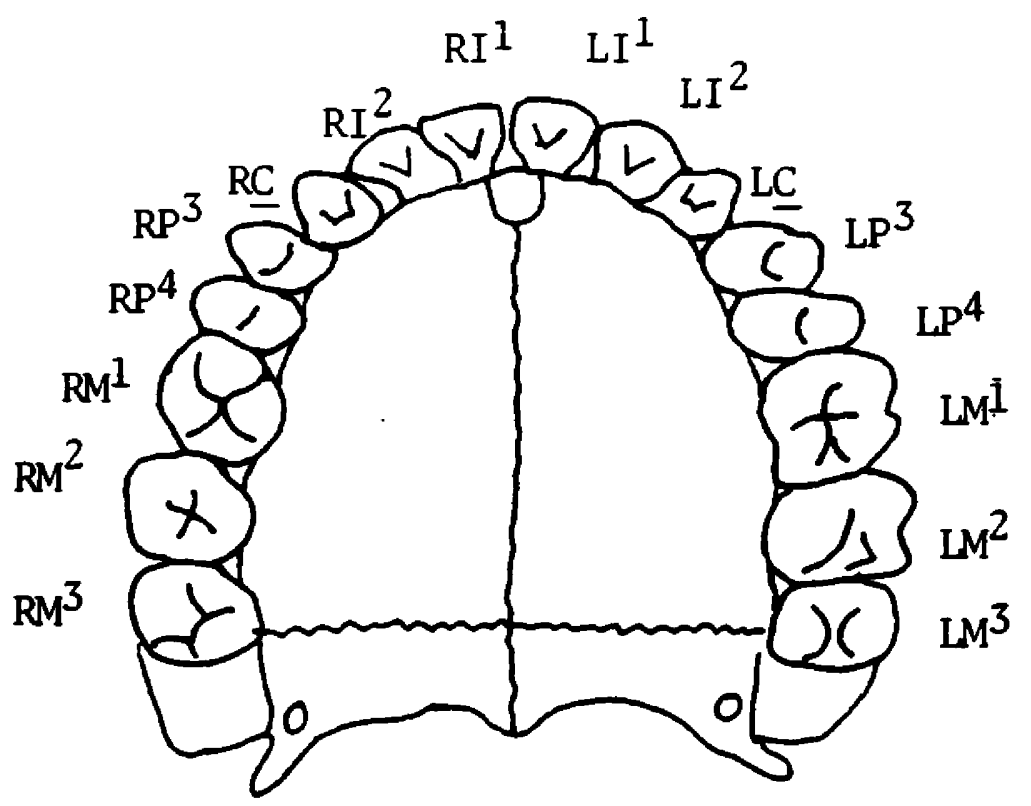

Figure 11

Diagram of normal human maxilla with teeth named. 


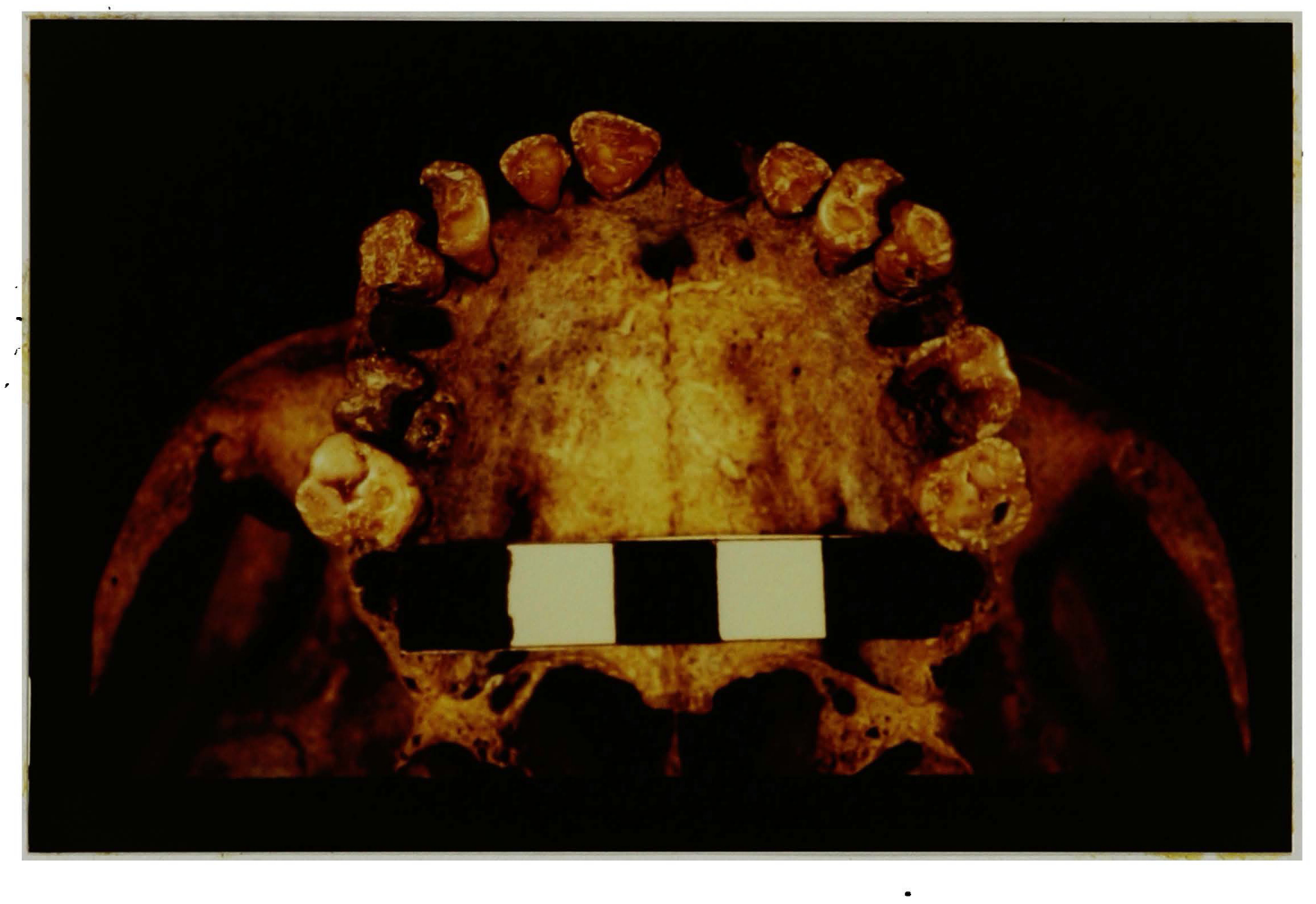

Figure 12. Palatal view of Lowie Museum specimen 3960. Scale in cm. 
LOWIE SPECIMEN 3963 (Figs. 3, 13)

In this specimen the condition of the teeth is excellent. There is no crowding except in the area of the transposition where the canine is positioned slightly labially to the tooth row and is crowded by the premolars. The $L P^{4}$ is rotated approximately $30^{\circ}$ posteriorly. Both canine roots are undeformed.

\section{LOWIE SPECIMEN 3977 (FIgS . 14, 15)}

The condition of the dentition in this specimen is very poor. In general the anterior dentition is a jumble. The canines are massive. Their roots are extremely curved, to the degree that the left canine enters the arcade at a $30^{\circ}$ angle and actually touches $\mathrm{LI}^{2}$ creating a triangular space where the LP $^{3}$ was. The socket for the $\mathrm{P}^{3}$ is very small, indicating that the tooth was reduced. The RPa was better developed than the $\mathrm{P}^{3}$. The socket indicates that the tooth position was anterio-lingual to the $\mathrm{RC}$ and rotated $90^{\circ}$.

LOWIE SPECIMBN 3994 (FIg. 16)

This is another specimen in which the dentition is excellent. On none of the teeth is the wear greater than 3 . on the left side the socket for the $P^{3}$ is lingual to the 


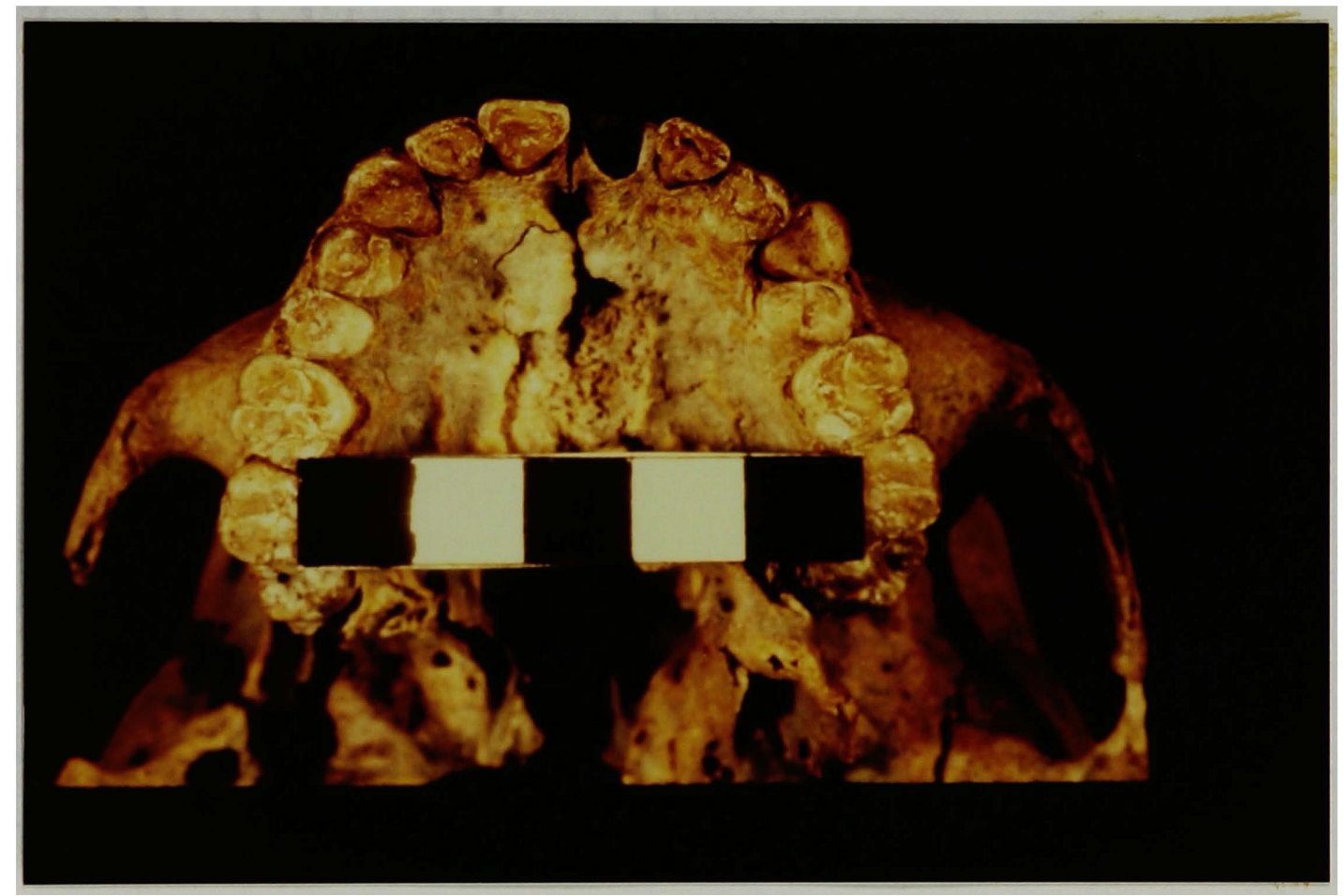

Figure 13. Palatal view of Lowie Museum specimen 3963. This is the same individual as in figure 3. scale in $\mathrm{cm}$. 


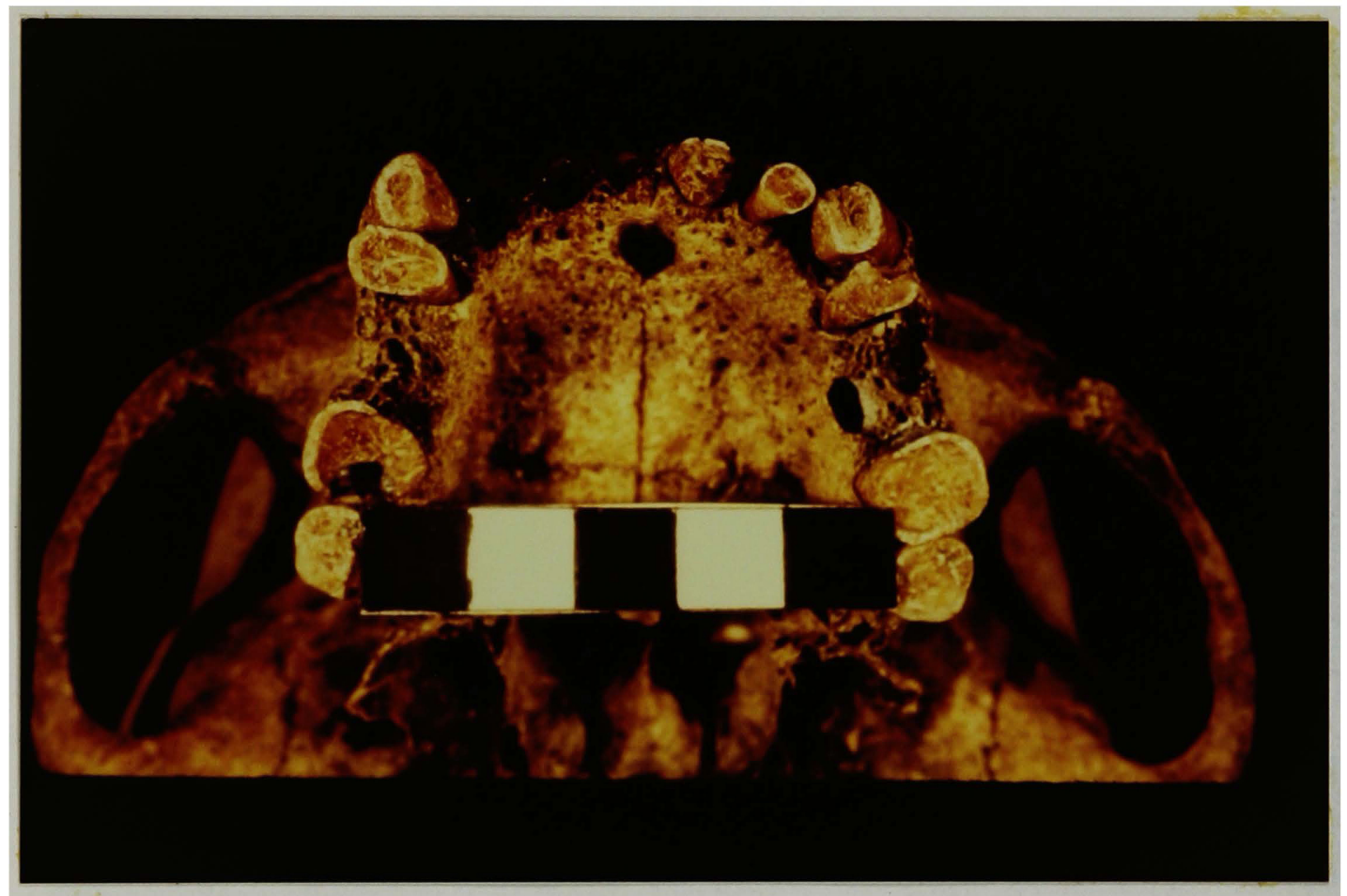

Figure 14. Palatal view of Lowie Museum specimen 3977. Scale in cm. 


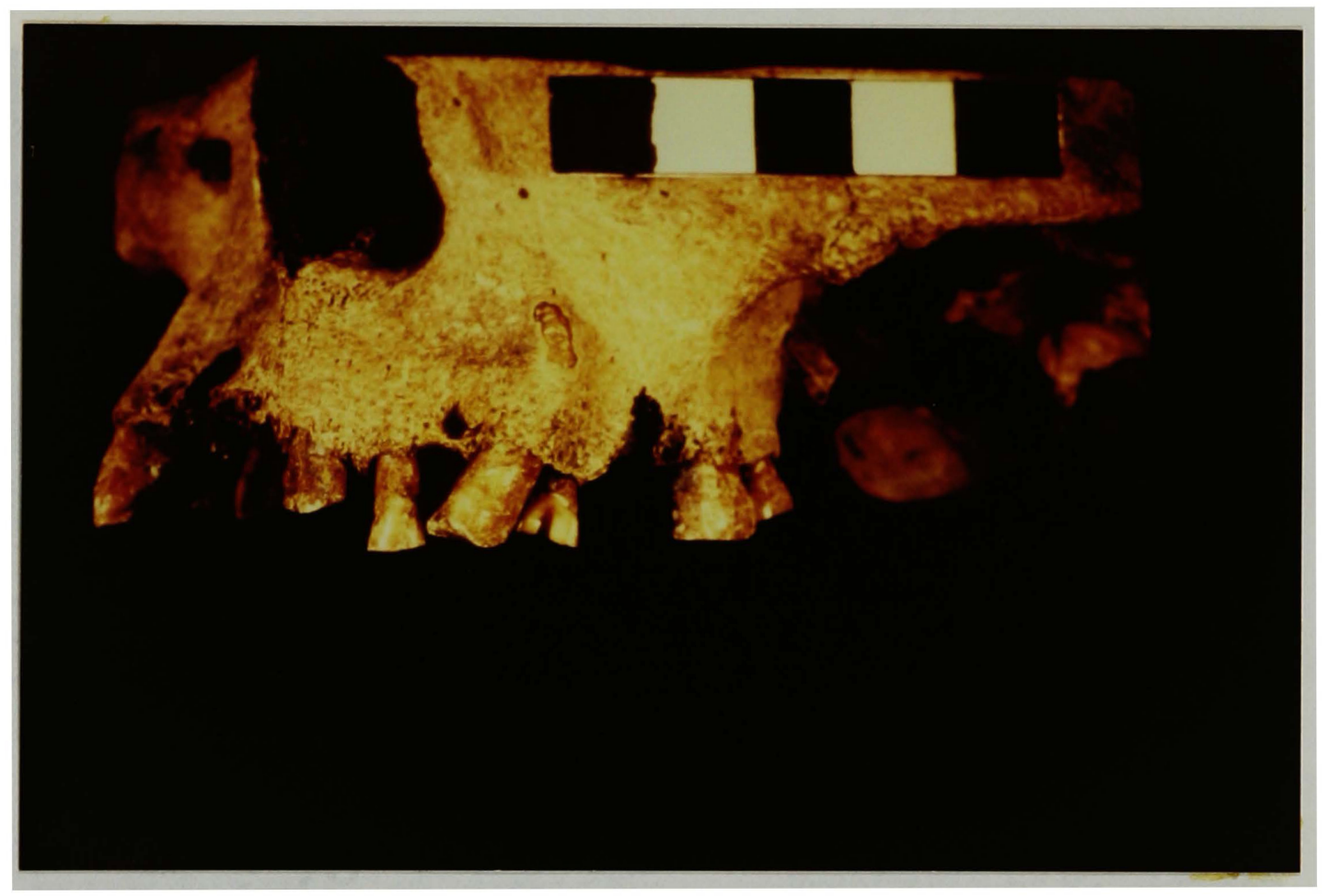

Figure 15. Left lateral view of Lowie Museum sperimen 3977. Note the extreme angle of the left canine and the triangular space where the premolar was. scale in $\mathrm{cm}$. 


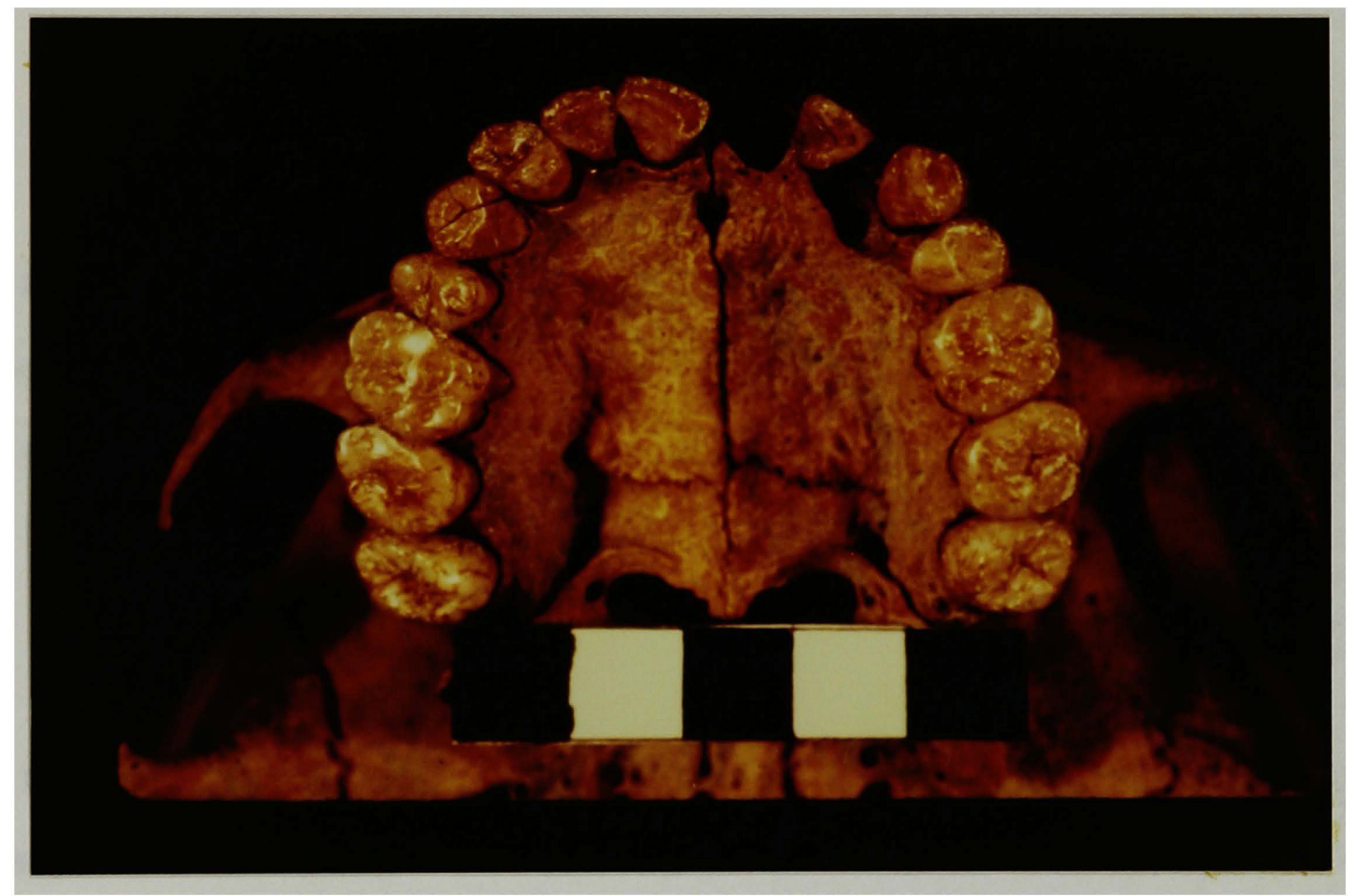

Figure 16. Palatal view of Lowie Museum specimen 3994 . The socket for the left premolar is lingual to the tooth row and rotated $90^{\circ}$. scale in cm. 
canine and rotated $90^{\circ}$. The rotation could be an effect of crowding but the gap between the $I^{2}$ and the canine is large enough to have accommodated the $P^{3}$ had it erupted correctly. The right side of the arcade is apparently perfect except for the transposition, The roots of the canines are well developed, with the root of the RC. being straight and robust. The root of the LC however, is slightly curved in a posterior direction at the end, but is otherwise straight.

\section{LOWIB SPECIMEN 3999 (FIg. 2)}

with this specimen there is no evidence of crowding. In fact the anterior teeth are well spaced. Both the right and left canines appear to be straight and undeformed.

\section{BMNH SPECIMEN SK 10009 (Fig. 17)}

In this specimen the teeth anteriok to the canines are missing. wear on the remaining teeth are not greater than 2+. On the left side the $P^{3}$ is rotated about $30^{\circ} 1$ abially and is slightly lingual to the tooth row. The canine and $p^{4}$ are oriented normally and are in line with the $M^{2}$. The RP $^{3}$ is rotated labially $40^{\circ}$ and is lingual to the tooth row. Except for the canine, which is slightly iabial to the tooth row, the rest of the arcade lines up normally. 


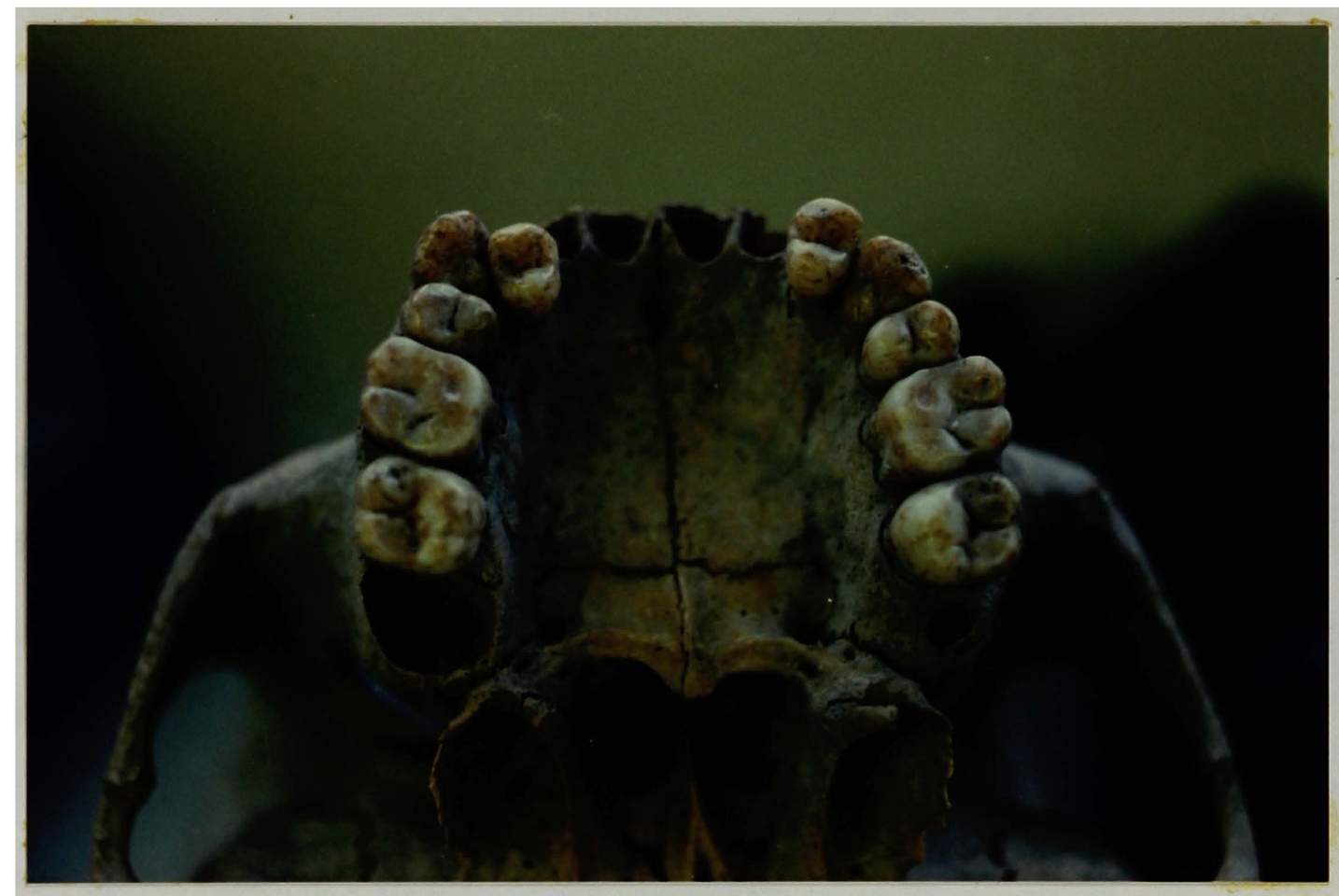

Figure 17. Palatal view of British Museum specimen sk10009. Pinching is quite noticeable in this individual. 
This is a very old individual. Although most of the teeth are missing, and there has been some resorption, on either side the canine is the fourth tooth back from the midline. Also, the sockets that are on either side of the canines are characteristic of premolars. On the right side the socket for the $P^{3}$ is rotated $20^{\circ}$ labially. The left side appears to have been normal except for the transposition.

\section{BMNH SPBCIMEN SK 10037 (FIg. 19)}

This is also an aged individual. The wear on the teeth is extreme and both $M^{2}$ 's are abscessed. There is slight crowding in the $\mathrm{P}^{3}-\underline{C}-\mathrm{P}^{4}$ region on both sides. In this specimen the incisors have been worn down to the roots and there are sizeable gaps between the $I^{21} s$ and $P^{3} s$. The canines are robust with long roots.

\section{BMNH SPECIMEN SK 10120 (FIg. 1)}

This individual is especially noteworthy because he retains the $\mathrm{Rdi}^{3}$ which is located between the $\mathrm{RI}^{3}$ and $\mathrm{RP}^{3}$. It is possible that the Ldiz was also retained as there is a hint of a socket between the $L^{2}$ and $L^{3}$. The remaining 


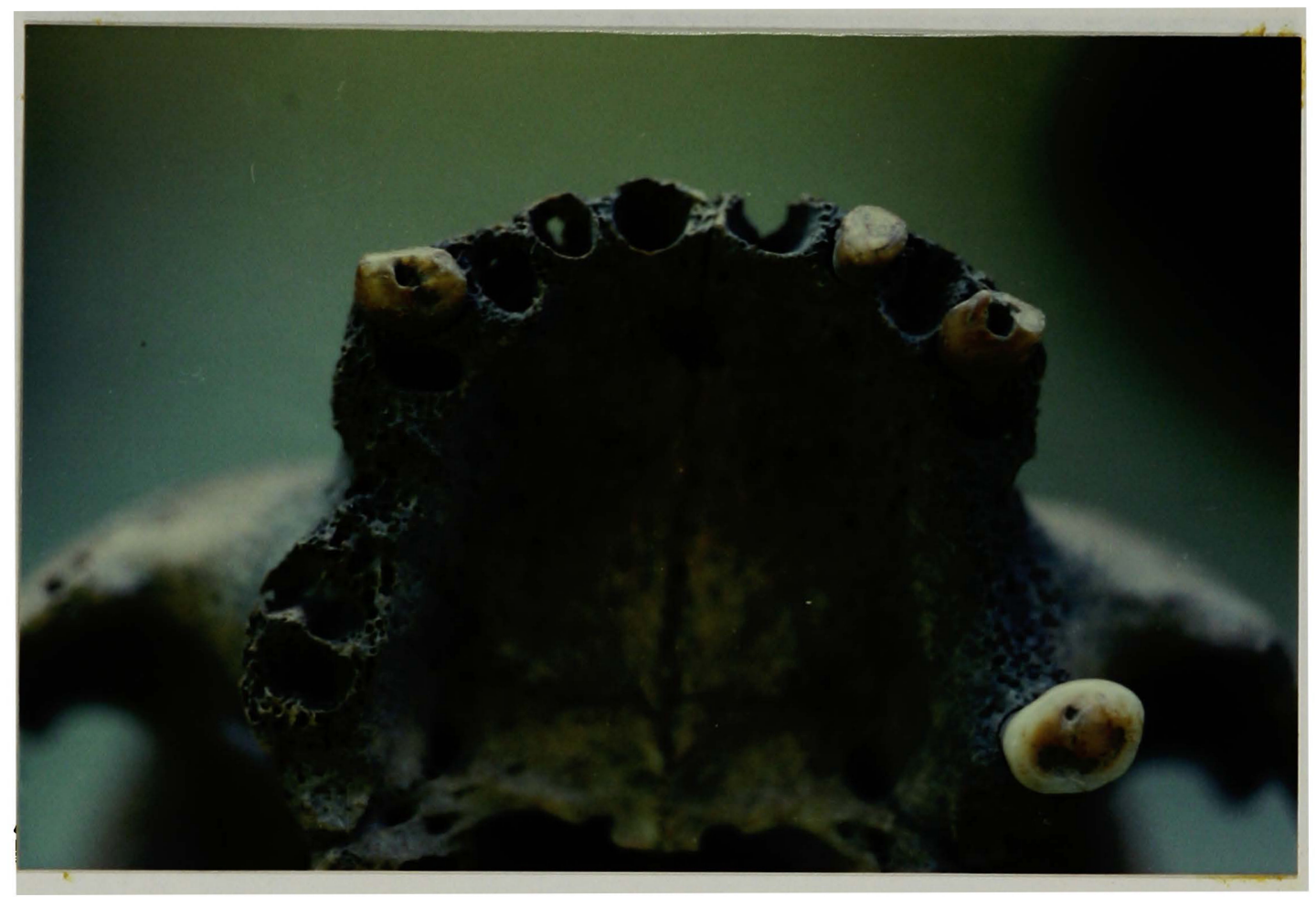

Figure 18. Palatal view of British Museum specimen sk10012. Although this is an aged individual the canines are the fourth tooth back from the midline and the sockets on either side are characteristic: of premolars. 


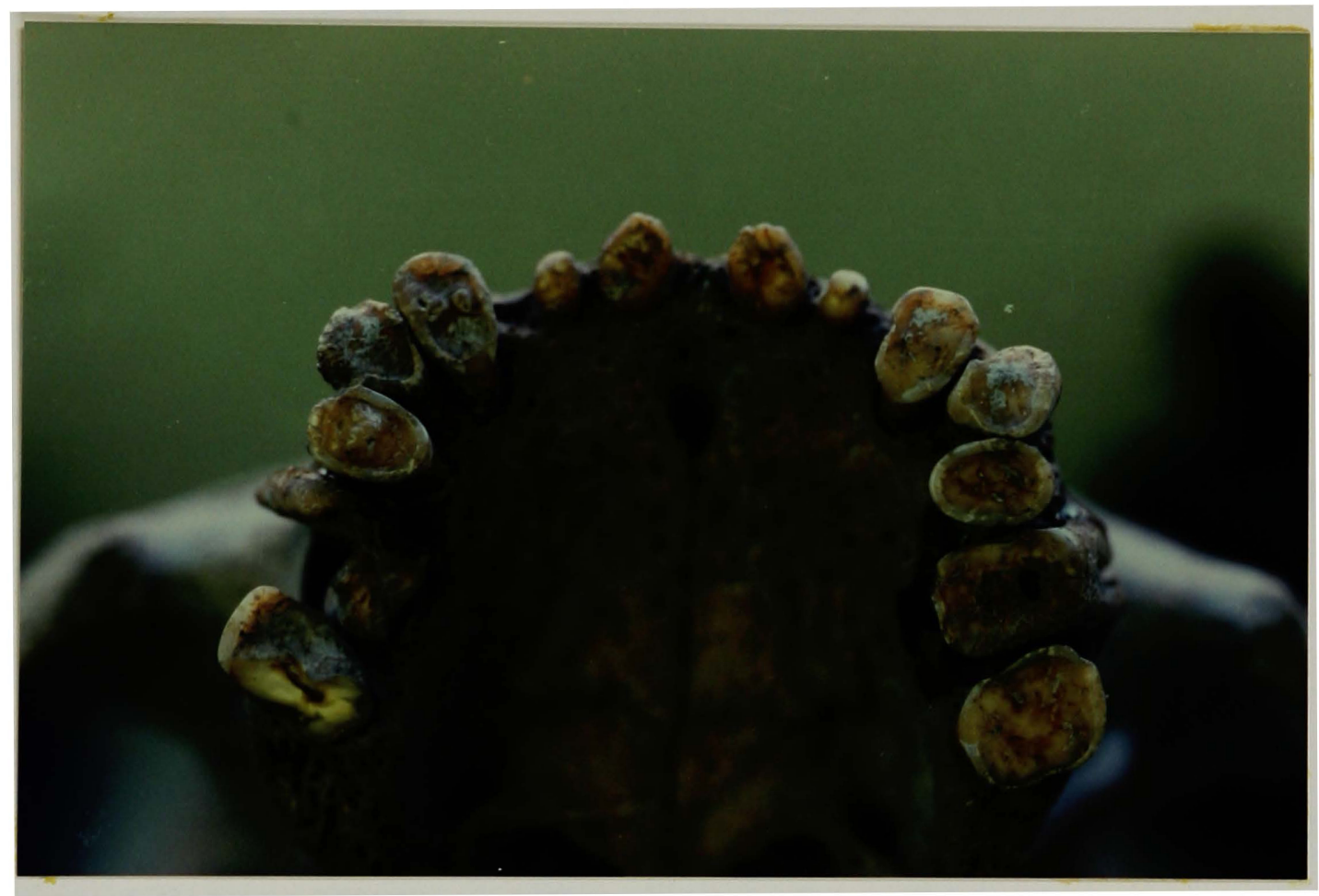

Figure 19. Palatal view of British Museum sperimen SK 10037 . 
teeth are heavily worn and the $\mathrm{LM}^{2}$ is abscessed. The canine roots are long and robust. The ends of the roots make fairly sharp medial curves that approach $90^{\circ}$. 


\section{CHAPTER 4}

Materials, Method, and Results

The skeletal material recovered from scri-3 was split between the Lowie Musemm at the University of california at Berkeley and the British Museum of Natural History. The transpositions were initially discovered among specimens from the Lowie Museum.

The method used to determine root placement is quite simple. From alare, generally defined as the most lateral point on the nasal opening, a line perpendicular to the midsagittal line was taken until it intersected a line from the center of the canine root at a right angle. The distance from this point to alare was measured (ser Fig. 20). The 32 measurements of normally-erupted canines are dérived from fifteen Native American crania housed in the Physical Anthropology Lab at the university of Montana and the two non-anomalous canines from the scri-3 sample. Measurements were done with vernier calipers accurate to $0.1 \mathrm{~mm}$.

After examining the material at Berkeley as well as that from the British Museum, a total of 106 crania were found in which tooth position could be determined. Nine of these exhibited the anomaly, resulting in the very high occurrence rate of 8.5 percent. 


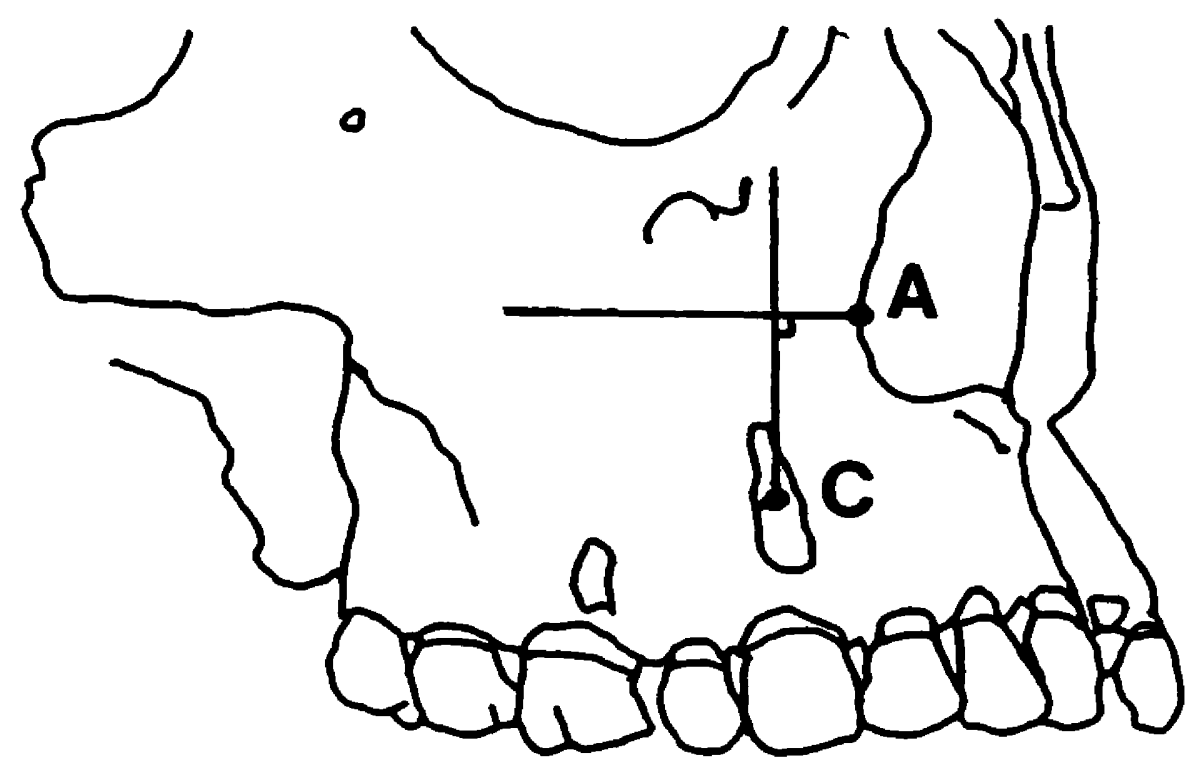

Figure 20. Diagram showing derivation of canine root measurements. A=Alare; C=Canine root midpoint. See text for explanation. 


$$
\text { Results of the analyses of distance are shown in tables }
$$

6 and 7 . The sixteen anomalously erupted canines averaged $8.96 \mathrm{~mm}$ from alare with a range of $5.9 \mathrm{~mm}$ to $12.0 \mathrm{~mm}$. The sample of 32 normally erupted ánines averaged $4.43 \mathrm{~mm}$ with a range of $2.5 \mathrm{~mm}$ to $6.9 \mathrm{~mm}$. The distance differential here is significant as the anomalous canines averaged twice the distance from the nasal opening as normal teeth, suggesting that the teeth not only erupted anomalously but that they originated and formed in this position. 


\section{Table 6}

Measurement.s of anomalous canines:

distance (in mm.) from alare.

\begin{tabular}{ccc} 
Specimen & Right & Left \\
LM \#3960 & 9.9 & 10.4 \\
LM \#3963 & Normal & 9.5 \\
LM \#3977 & 11.0 & 11.1 \\
LM \#3994 & 5.9 & 7.8 \\
LM \#3999 & Normal & 6.8 \\
BMNH \#.SK 10009 & 8.0 & 7.0 \\
BMNH \#SK 10012 & 8.5 & 9.0 \\
BMNH \#SK 10037 & 8.0 & 7.5 \\
BMNH \#SK 10120 & 11.0 & 12.0 \\
\hline
\end{tabular}

Total Right $=62.3$

Total LeEt $=81.1$

$$
\frac{81 \cdot 1}{143 \cdot 4 / 16 \quad \bar{x}=8.96}
$$


Table 7

Measurements of normal canines; distance (in mm.) from alare.

Specimen Right Léft.

$\mathrm{UM} \# 27$

4.9

5.2

JM \#6178

3.2

3.6

UM \#6906

4.9

$4 \cdot 1$

UM $\cong 6907$

3.0

5.3

UM \#6912

6.9

6.3

UM \#6913

4.9

4.5

UM \#6914

5.3

5.4

UM \#6915

5.4

4.3

UM $\$ 6916$

4.4

3.5

$24 \mathrm{CB} 250$

3.2

4.0

24 RL 11

4.2

3.9

UM unnumbered

4. 8

4.5

UM unnumbered

4.3

2.5

UM unnumbered

5.5

4. 0

UM unnumbered

4.0

3.8

LM \#3963

4.5

Anoma 1ous

LM \#3999

3. 3

Anomalous

Total Right $=76.7$

Total Left $=64.9$

$$
\overline{141.6 / 30} \bar{x}=4.43
$$




\section{CHAPTER 5}

Discussion and Conclusion

DISCUSSTON

In support of a genetic origin for the anomaly is a report by feichtinger et al. (1977) where they describe a case in which $\underline{c} / \mathrm{P}^{3}$ transposition occurred in three of eight children of a second cousin marriage. They conclude that "the pedigree fof the affected familyl shows the typical hereditary pattern of an autosomal recessive trait" (p. 1450). Pindborg (1970) also mentions two brothers who exhibit bilateral transposition, an indication that heredity might also have played a role in another case.

As for the scri-3 material several factors point to a genetic role and support Feichtinger et al. (1977) concerning the etiology of $\mathrm{C}^{3} \mathrm{P}^{3}$ transposition.

1) All specimens are from one site and approximately the same time period.

2) More specifically, all are buried in the same general area within the cemetery with two of the nine being next to each other (Olson, n.d.). This close association might indicate the family ties which would be expected if we were dealing with the manifestation of a recessive trait.

3) The anomalous placement but normal form of the canine root.

4) The high probability that santa cruz Island was, to a degree, genetically isolated from surrounding populations. 
Both this research and the pedigree analysis by Feichtinger et al. (1977) point to à genetic origin for this anomaly. However, two questions remain: when during the development of the maxilla does the transposition originate? and, are other pressures a factor? The answers to these questions lie in the formation and development of the teeth and paraoral structures, specifically in the areas of early embryonic development and eruption. These are the times in which genetic and developmental pressures exhibit themselves.

It is important to first note that the tooth and the structures that surround it are genetically determined units, each of which may affect the others' growth and development. The teeth begin to form starting about the sixth week of embryonic development. At this time a proliferation of cells on the crest of the rudimentary maxilla produces a strand of epithelium known as the dental lamina. Bud-like swellings appear in about the tenth wekk as certain areas of the dental lamina proliferate mort rapidly than others. These growths of epithelium are the beginnings of individual tooth formation and are the tooth buds for the deciduous dentition. It is after these primary teeth are formed that the dental lamina, developing in the same way as with deciduous teeth, produces secondary buds that will become the permanent teeth (Kerr and Ash, 1978; Cohen, 1984). 
Inherent in this process of tooth formation are certain developmental steps that lead to the formation of any organ, not just teeth. These steps involve a sequence of events that includes induction of cell groups, cellular migration, cellular interaction with a new "environment.", and differentiation into specific tissue types (Dixon and stewart, 1976; Kollar and Lumsden, 1979). It is during the second of these steps, cellular migration, that transpositional anomalies are likely to originate. At this time moving epithelial cells "test" positional information, put out by the mesodermal cells over which they move, by matching protein chains. When they contact cells at the site for which they are programmed they stop. The mutation which causes the anomaly may lie within the mesodermal organizer genes (Dixon and stewart, 1976), in that the cel1s producing canine and $\mathrm{P}^{3}$ placement proteins arise in reversed order along the developing maxilla, causing the canine and popithelial cells to attach in a transposed position. once these tooth cells have attached, they are set in position and proceed to develop and grow normally.

Although it would appear that growth and developmental pressures would have an effect on tooth position, as it does in crowding, this explanation has some difficulties. Once the tooth has begun to grow, a bony crypt forms around it protecting it from external forces until eruption (Goose and Appleton, 1982; Cohen, 1984). As several of the scri-3 
examples exhibit various degrees of crowding and tooth rotation, conditions which are gererally caused by other developmental pressures and which manifest themselves during the eruption process, it is easy to see how investigators might propose this as the etiology of transpositional anomalies. Dixon and stewart (1976, Fig. 6-1; Fig. 21, this paper) listed transpositional anomalies with impaction and delayed eruption as conditions that develop during eruption, while Pindborg (1970) mentioned cysts as one possible cause. In the scri-3 material there is no evidence of cysts of any kind and except for LM3994, in which the LP ${ }^{3}$ is 1 ingual and rotated $90^{\circ}$, other developmental disturbances are minor. The one type of crowding that does appear in seven of the nine crania results in the pinched appearance of the transposed canines in these specimens (Figs. 1, 12-14, 1719). This pinching can be explained easily if several interrelated factors are taken into account. First, the canine normally erupts slightly buccally in comparison to its adjacent teeth, giving the impression of its being a "cornerstone" of the arch (Becker et al., 1981). second, the reduction of the human face leaves a relatively small space for the growth of the human dentition. And third, the teeth erupt in sequence.

The eruption sequence (see also Fig. 22) in the C-Pa-p area is highly variable. For the ten state survey data discussed by smith and Garn (1987) the eruption sequence 
Hypoplastic type Aro'ogenesis imperfocta

Dentincgenesis imperfecta

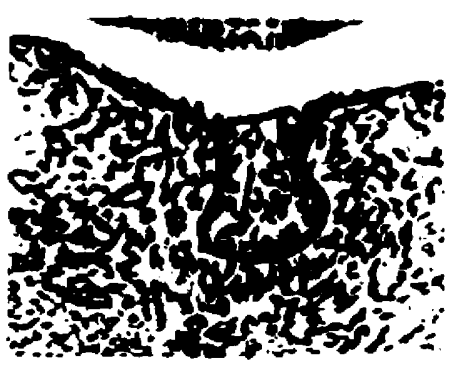

INITIETION PRO'IFEFATION
Supernumerary teetr.

Natal teet?

Epithelial rests

Gemination
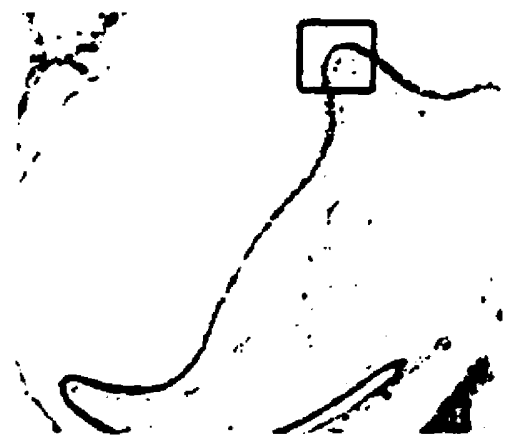

HISTODIFFERENTIATION

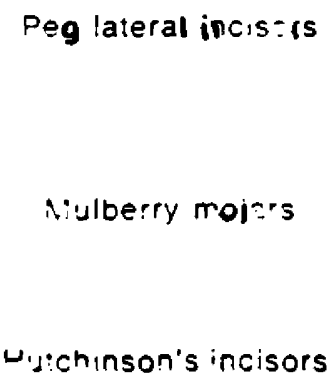

Microdentia

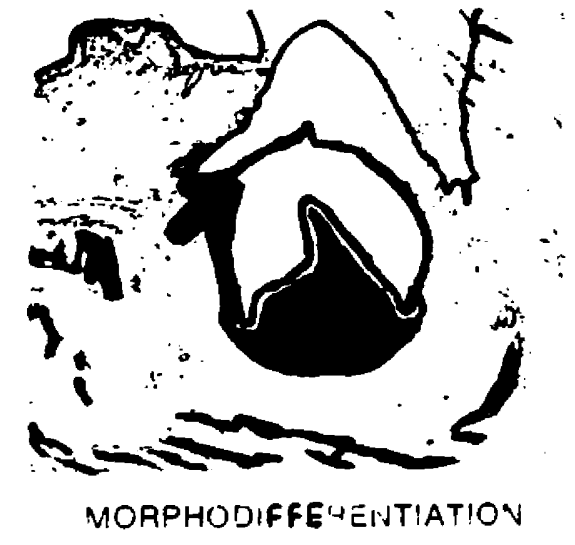

Figure 21.
Tuberculates i...s.

Carabellı = eusp

Macrodontia

Taurogimia

Dens in dente

Figure 6-1 from Dixon and Stewart, 1976. 


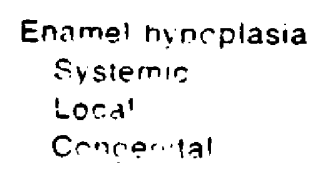

Dentinnd:?

Hypacalc. ied type Amelonenesis :mperfecta

Miclled enamel
nteratuhislal dentin

Traneposition

Deiaved eruption
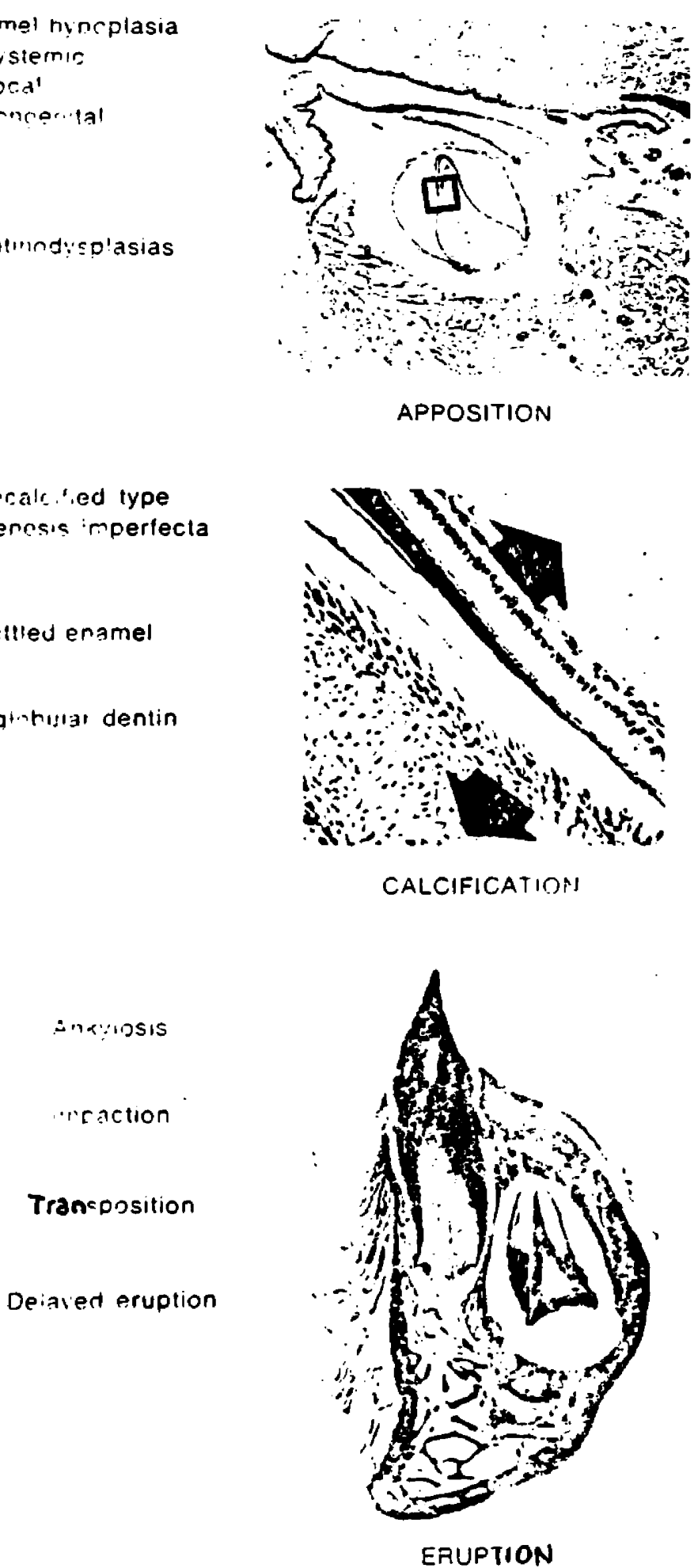

APPOSITION

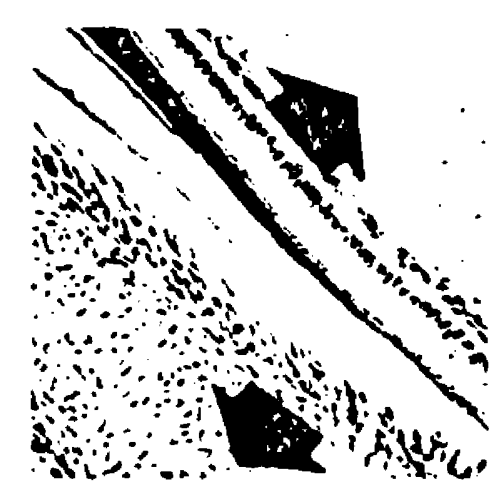

CALCIFICATIOH

Figure 21, contimued.
Ename, pearis

Hypercementosis

Odontoma
Neonatal ieeth

Precocious eruption 


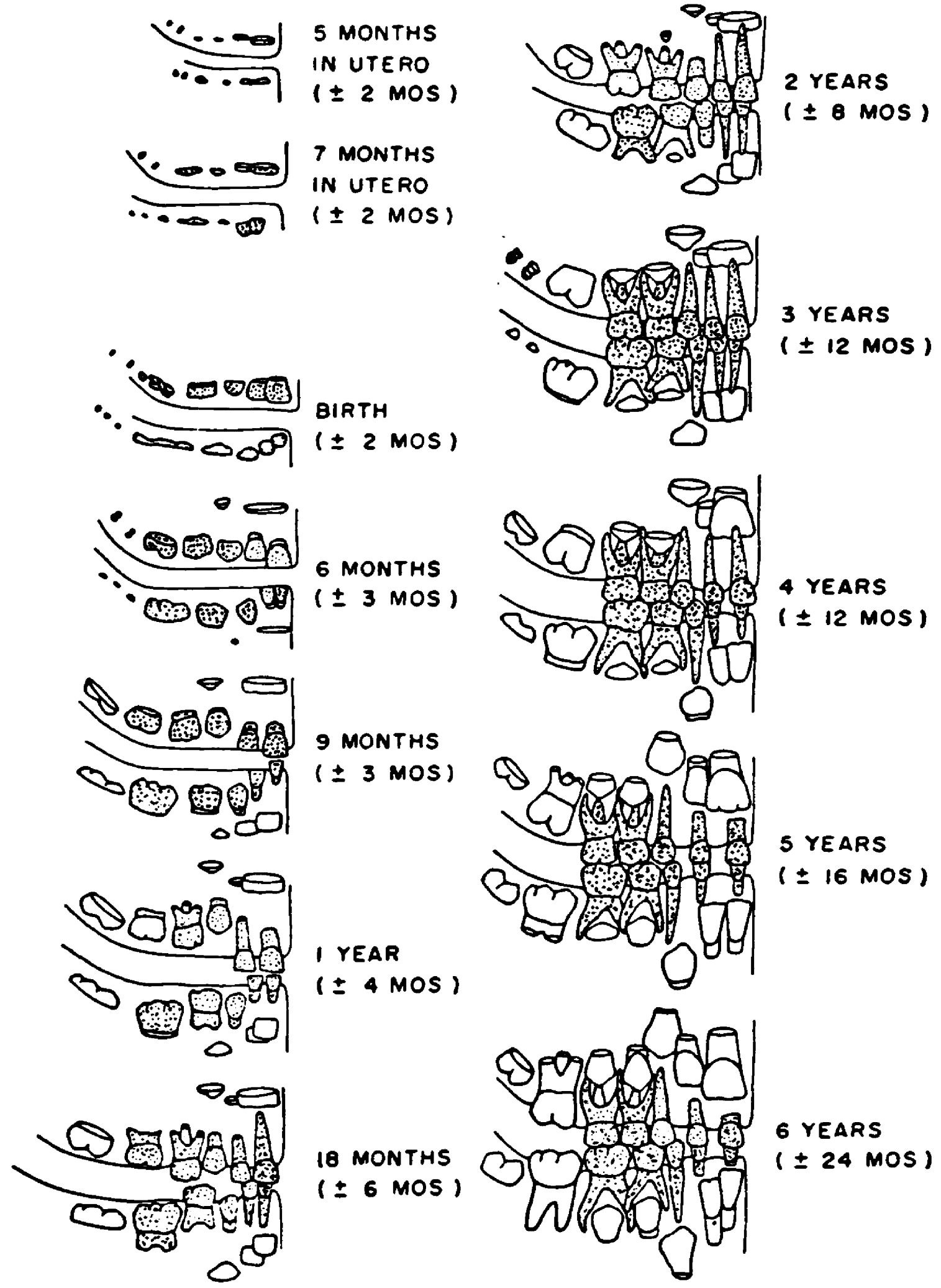

Figure 22.

Tooth eruption chart, deciduous dentition is stippled (adapted from Ubelaker, 1978). 

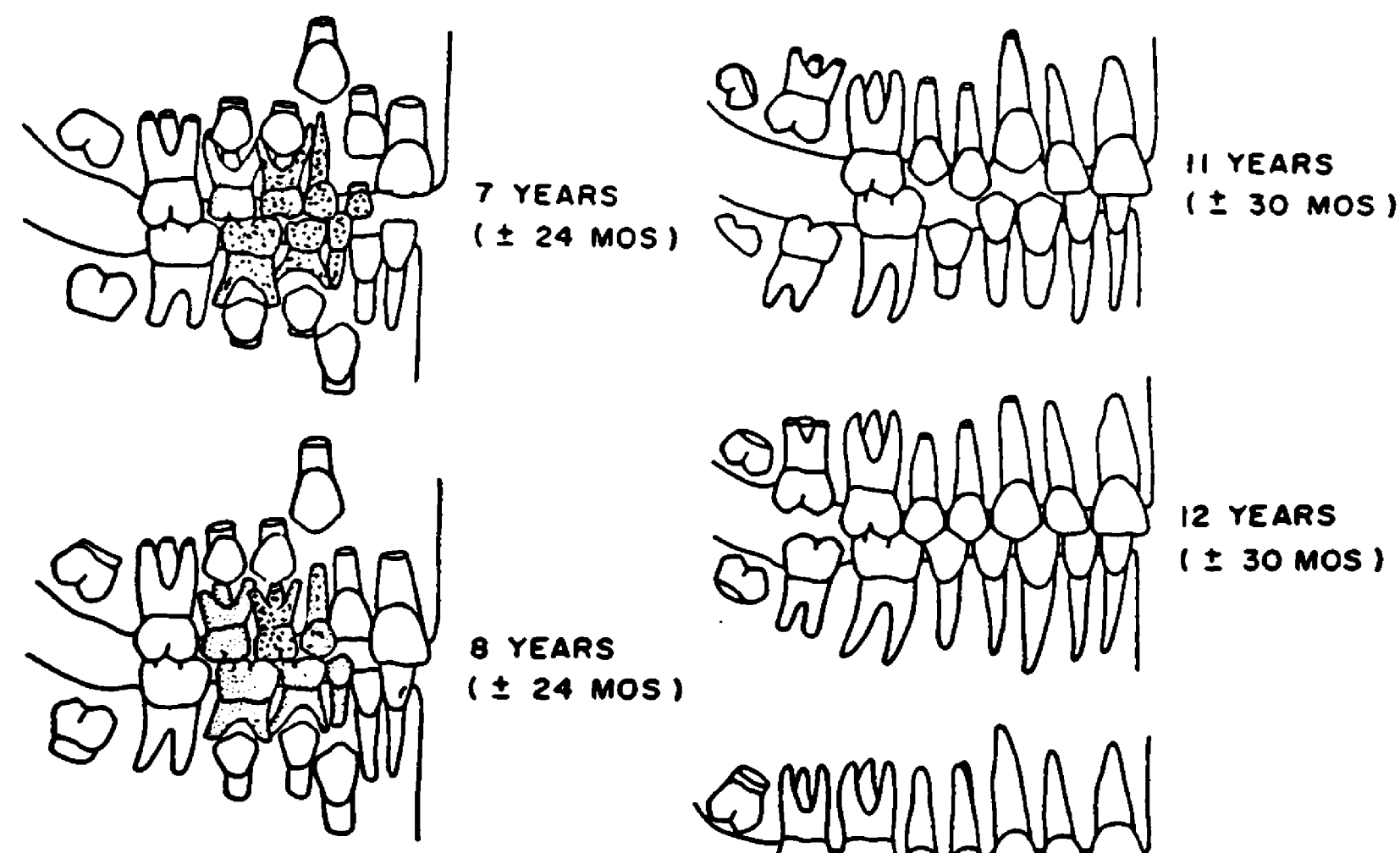

8 YEARS

( \pm 24 MOS)

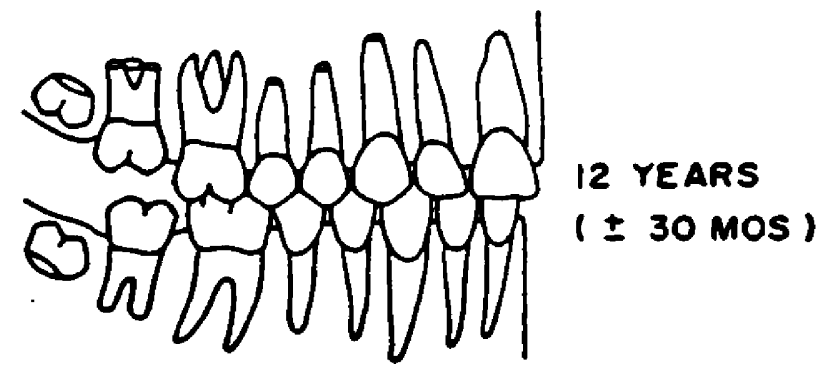

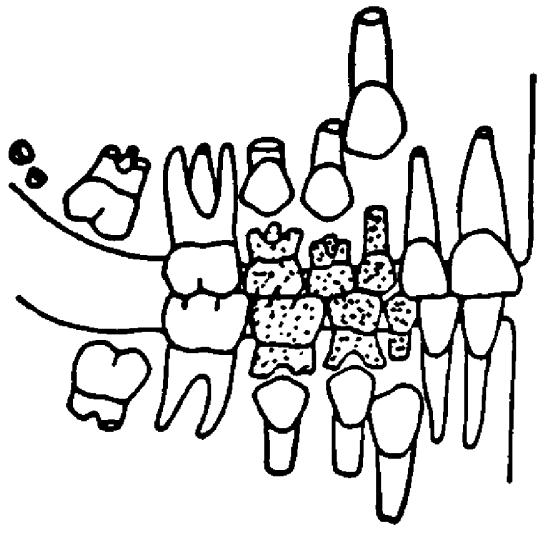

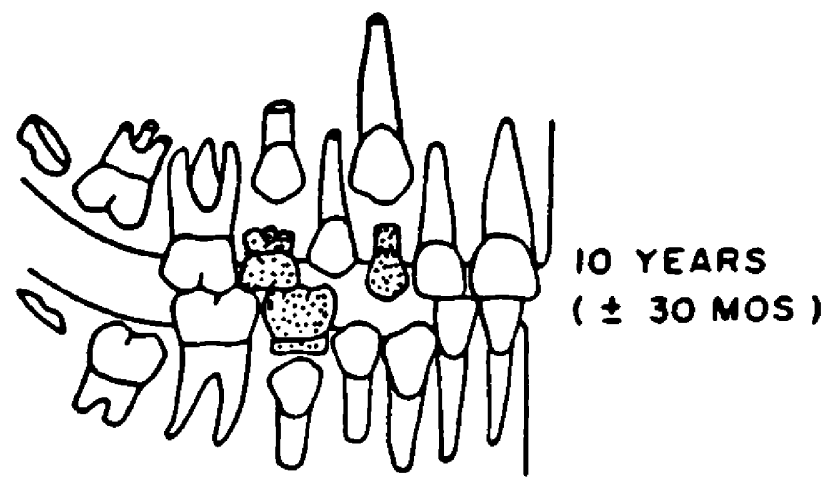

9 YEARS ( \pm 24 MOS $)$
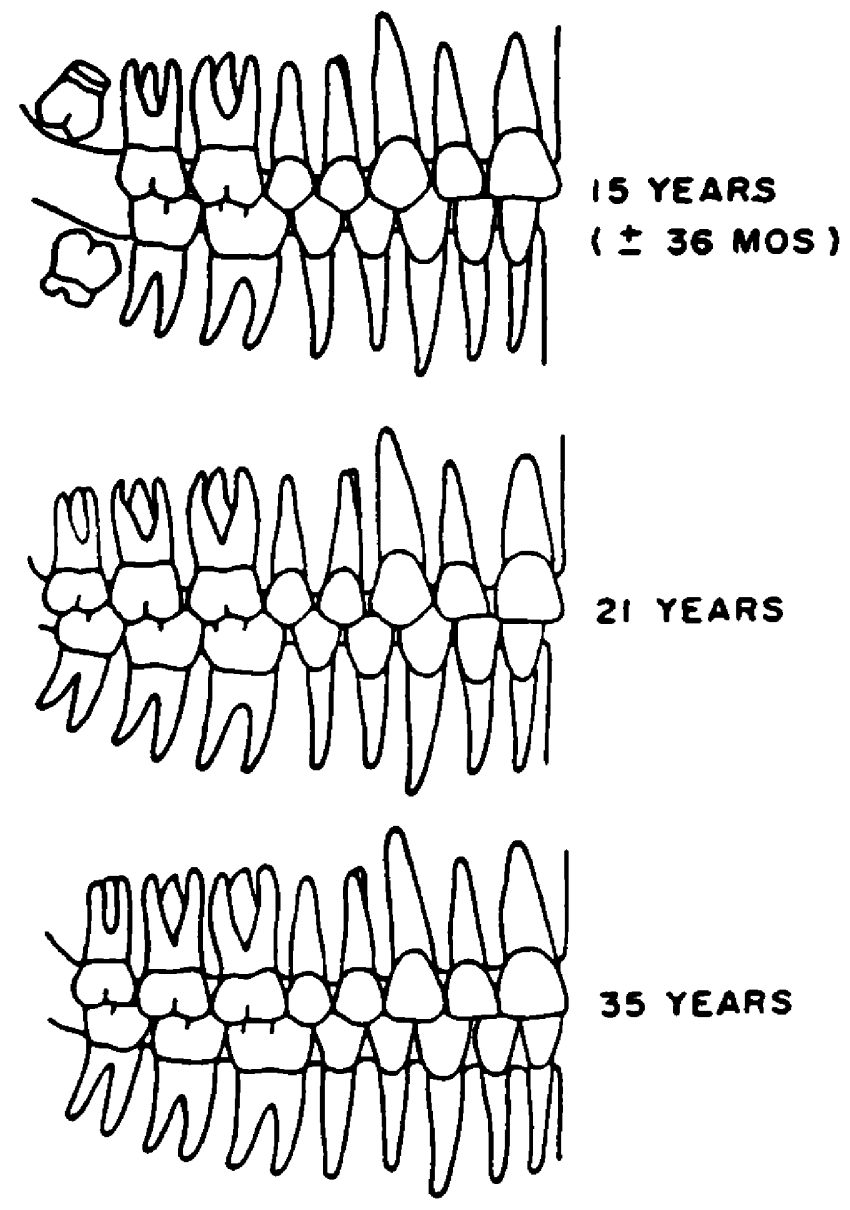

Figure 22, continued. 
for the entire data set is $\mathrm{P}^{3}-\underline{C}-\mathrm{P}^{4}$, although for the white males subset the sequence of $\mathrm{P}^{3}-\mathrm{P}^{4}-\mathrm{C}$ oraurs $57 \%$ of the time. Both Jaswal's (1983) study of the khasis of India and that. of Mayhall et al. (1978) of Inuit children indicate an eruption order of $P^{3}-P^{4}-C$. If we are to consider the sequence $\mathrm{P}^{3}-\mathrm{P}^{4} \underline{-\underline{C}}$ "normal", though variable, this would create a situation in which the normally growing (but transposed) canine must find space between the already erupted premolars. As this space may not fully be there, the canine would be forced to erupt noticeably buccally to the tooth row. Therefore, this type of crowding, and probably any other abnormal crowding that affects the transposed teeth, is, if anything, a consequence of the transposition, not a cause.

one interesting facet of $\mathrm{C}_{\mathrm{P}} \mathrm{P}^{3}$ transposition is that it runs counter to one of the most prevalent, though embattled (see Kieser, 1986), current theories of dental development. Butler (1939) basing his work on biological field theories developed by Huxley and de Beer (1934), proposed that teeth develop in concert with specific developmental fields. In this theory there are three dental fields, incisor, canine, and molar, in which teeth of a specific type develop. Each field is anchored at a center point, $M^{2}$ for example, from which the fields influence wanes the farther from the center development takes place (Butler, 1982; Kieser, 1986). In this model the $M^{3}$ is variable, which it is, because it is 
distant from the center of the field. Thherent also in this model is the idea that a fields influence ends at the border with a different field. In other words, canines are not affected by the molar field. If this were the case c/po transposition could not happen, but because it does the validity of the field theory is thrown into question.

\section{CONCLUSION}

As far as the direct mechanism for the expression of the anomaly is concerned the position of Feichtinger et al. (1977), that it is the manifestation of a recessive trait, seems likely to be correct. The population from which the scrI-3 material comes was probably not large and was also relatively isolated on the island folson, 1930; Heizer and Whipple, 1971; Glassow, 1977). These factors could increase the probability of inbreeding, and therefore, raise the chances for the expression of a recessive trait such as canine/third premolar transposition.

when the existence of this anomaly at a high frequency in a small group is combined with the results of the canine root measurements, the pedigree analysis by feichtinger et. al. (1977), and an understanding of how the teeth and paraoral structures develop, the only plausible conclusion seems to be that transpositional anomalies are genetic in origin. As it appears that once the cells that are to 
become specific teeth locate along the developing dental arch, they are fairly impervious to external developmental pressures, it follows that these external pressures would have little or no effect on a genetic anomaly such as transposition. This is supported by the scri-3 material in which the large difference in location between normal and transposed canines, as well as the undeformed nature of their roots, indicates that the transposed teeth developed and grew in their reversed position. 


\section{GLOSSARY}

Apposition:

The growth of successive layers of the developing tooth.

Dental Lamina: strand of epithelium on the crest of the rudimentary maxilla from which the teeth grow.

Differentiation: The appearance of functionally and morphologically distinct cell typess.

Epithelium: Membranous tissue, usually a single cell layer, forming the covering of most internal surfaces and organs. The outer layer of the developing Maxilla.

Histodifferentiation: The bell stage of dental development. Disproportionate proliferation of the developing tooth, following the oap stage. The disproportionate nature of this segment. of proliferation creates a bell shaped structure that continues to increase in size and morphological complexity until the basic: crown form is completed.

Induction :

A process by which certain cellular grougs mediate and direct the differentiation of adjacent cellular groups. 
Initiation:

The bud

( $\mathrm{E}$ irst)

st.age

in

dentà 1

development. The initial proliferation of cells that will lead to the formation of teeth.

Interaction: Process in which different rells join. In early dental development the time at which the mesodermal cells match protein chains with ceils of the dental lamina.

Mesoderm; Mesodermal eel1s: The embryonic: germ (cel1) layer from which develops connective tissue, muscles, and the urogenital and vascular syst.ems.

Mesodermal organizer Genes: Genes which control the location of cell surface proteins on mesodermal cells. Aberrant cell surface proteins could lead the epithelial cells to attach in the wrong place.

Migration: The movement of cells to a designated location where they proliferate and grow into specific tissues or organs.

Paraoral: Near or beside the mouth.

Proliferation: Increase in the rate of cell growth in a specific area. It is the beginning of a specific: structure or organ. The cap (second) stage of dental development. 
supernumary Teeth: Extra, usually out of place, teeth; ie. a thicd canine growing in the roof of the mouth.

Tooth Bud:

The beginnings of the formation of an individual tooth. They begin as knoblike invaginations on the lateral surface of the dental lamina. 
Becker, A., P. Smith, and R. Behar

1981 The Incidence of Anomalous Maxillary Lateral

Incisors in Relation to Palatally-Displaced cuspids.

The Angle orthodontist 51(1):24-29.

Butler, P.M.

1939 studies of the Mammalian Dentition. Differentiation of the Post-canine Dentition. $\frac{\text { Proceedings of the Zoological society of London }}{109}$ B:1-36.

Butler, P.M.

1982 Some Problems of the ontogeny of Tooth Patterns.

In Testh: Form, Function, and Evolution, edited by

B. Kurten, pp. 44-51. columbia University Press, New York.

Brothwe11, D.R.

1981 Digging Up Bones. Connell University press, Ithacea.

Cavalli-sforza, L.L., and W.F. Bodmer

1971 The Genetics of Hunan Populations. W.H. Freeman,

san Francisco.

Cohen, R.L.

1984 Clinical Perspectives on Permanent pooth Eruption and cyst Formation in Neonates. Pediatric Dermatology $1(4): 301-306$.

Dixon, G.H., and R.E. Stewart

1976 Genetic Aspects of Anomalous Tooth Development.

In oral Facial Genetics, edited by R.E. Stewart and G.H. Prescott, pp. 124-150. C.V. Mosby, st, Louls.

Feichtinger, C.H., B. Rossiwall, and H. Wunderer

1977 Canine Transposition as Autosomal Recessive Trait. in an Inbred Kindred. Journal of Dental Research $56: 1449-1452$.

Glassow, M.A.

1977 An Archaeological overview of the Northern Channel Is lands, California. Western Archaeological Center, National park Service, Tucson.

Goose, D.H., and J. Appleton

1982 Human Dentofacial Growth. Pergamon, oxford. 
Harrison, w.M.

1964 Prehistory of the sinta Barbara Coast California.

Doctoral Dissertation, University Microfilms, Ann Arbor.

Heizer, R.F., and M.A. Whipple, uds.

1971 The California Indians: A source Book, $2^{\text {na }}$ Edition. Jniversity of California pröss, Berkeley.

Hoover, R.L.

1971 Some Aspect.s of santa Barbara Channel Prehistory.

Doctoral Dissertation. Department of Anthropology. University of California, Berkeley.

Huxley, J.S., and G.R. de Beer

1934 The Elements of Experimental Embryology. cambridge University Press, cambridge. England.

Jaswa $1, \mathbf{s}$.

1983 Age and sequence of Permanent-Tooth Emergence Allong Khasis. American Journal of Physical Anthropology $62(2): 17 \overline{7-186}$.

Kerr, D.A., and M.M. Ash jr.

1978 oral Pathology. Lea and Fibiger, Philadelphia.

Kieser, J.A.

1986 Odontogenic Polarity and Butler's Field Theory.

Medical Hypotheses 20:103-107.

King, C.D.

1976 Chumash Inter-viliage Economic Exchange. In Native Californians: A Theoretical Retrospertive, edited by I.J. Bean and T.C. Blackburn, pp.288-318. Ballena Press, Socorro, New Mexico.

King, C.D.

1981 The Evolution of chumash society: A Comparative study of Artifacts used in social System Maintenance in the santa Barbara channel Region. University Microfilms, Ann Arbor.

Kollar, E.J., and A.G.S. Lumsden

1979 Tooth Morphogenesis: The Role of the Innervation During Induction and pattern Formation. Journal of Biology Buccale $7: 49-60$.

Kreober, A.L.

$1925^{\circ}$ Handbook of the Indians of California. Smithsonian Institution, Bureau of American Ethnology Bulletin \#78. 
Landberg, L.C.W.

1965 The Chumash Indians of southern California. Southwest Museum Papers 19 .

Mayhall, J.T., P.L. Belier, and M.F. Mayhall

1978 Canadian Eskimo Permanent Tooth Emergence Timing.

American Journal of Physical Anthropology 49:211-216.

Morrato, M.J.

1984 California Archaeology. Academic Press, New York.

Olson, R.L.

n.d. Field Notes From Fieid seasons 1927 and 1928 .

Housed at the Lowie Museum, University of California at Berkeley.

Olson, R.L.

1930 Chumash Prehistory. University of California

Publications in American Archaeology and Ethnology

Orr, P.C.

1968 Prehistory of Santa Rosa Island. Santa Barbara Museum of Natural History, santa Rarbara.

Pindborg, J.J.

1970 Pathology of the Dental Hard Tissues. W.B. saunders, Plitiadelphía.

Reid, R.M.

1973 Inbreeding in Human Populations. In Methods and Theories of Anthropological Genetics, edited by M.H. Crawford and P.L. Workman, pp. 83-116. University of New Mexico Press, Albuquerque.

Rogers, D.B.

1929 Prehistoric Man of the santa Barbara Coast. Santa Barbara Museum of Natura $\bar{l}$ istory, santa Barbara.

Schumacher, P.

1877 Researches in the kjottenmoddings and Graves of a Former Population of the Santa Barbara Islands and the Adjacent Mainland. Bulletin of the united states Geological and Geographical survey of the Territories 3:37-61.

Smith, B.H., and S.M. Garn

1987 Polymorphisms in Eruption sequence of Permanent Teeth in American Children. American Journal of Physical Anthropology $74(3): 289-30.3$. 
Ubelaker, D.H.

1978 Human skeletal Remains: Excavation, Analysis, Interpretation. Tăraxacum, washington D. C.

Walker, P.L.

1978 A Quantitative Analysis of Dental Attrition Rates in the Santa Barbara Channel Area. American Juurnal of Physical Anthropology 48:101-106.

Walker, P.I.

1986 Porotic Hyperostosis in a Marine Dependent California Indian Population. American Journal of Physical Anthropology 69:345-354.

Walker, P.L., and M.J. DeNiro

1986 stable Nitrogen and carbon Isotope Ratios in Bone collagen as Indices of Prehistoric Dietary Dependence on Marine and Terrestrial Resources in southern Califormia. American Journal of Physical Anthropology $71: 51-61$.

Walker, P.L., and J.M. Erlandson

1986 Dental Evidence for Prehistoric Dietary Change on the Northern Channel Islands, California. American Antiquity $51(2): 375-383$.

warren, C.N.

1968 Cultural Tradition and Ecological Adaptation on the southern california coast. In "Archaic: Prehistory in the western united states," Edited by C. Irwinwilliams, Eastern New Mexico university contributions in Anthropology, 1 (3):1 $-\overline{14}$. 